\title{
Insider Trading as Misfeasance: The Yielding of the Fiduciary Requirement
}

\author{
Joanna B. Apolinsky*
}

\section{INTRODUCTION}

Mark Cuban is a billionaire entrepreneur and active investor. ${ }^{1}$ One of his more recent ventures is as majority partner in Sharesleuth.com, a web-based reporting site "aimed at exposing securities fraud and corporate chicanery." 2 Mark Cuban has also made news of late as a defendant in an action brought against him by the Securities Exchange Commission (SEC) for insider trading. ${ }^{3}$ The SEC alleges that he violated section 10(b) of the Securities Exchange Act of $1934^{4}$ and 17 C.F.R. $\S 240.10 b-5$ (Rule 10b-5) ${ }^{5}$ when he sold his stock in Mamma.com, Inc. after the company's CEO told him material, confidential information concerning a private investment in public equity (PIPE) offering Mamma.com planned to make. ${ }^{6}$ Cuban owned a $6.3 \%$ stake of Mamma.com, making him the company's largest known shareholder. ${ }^{7}$ Before the announcement of the PIPE, Mamma.com's CEO called Cuban to let him know about the company's plans and to invite him to participate in the PIPE. ${ }^{8}$ Before apprising Cuban of the upcoming PIPE, the CEO first secured Cuban's assurance that he would keep the information confidential. ${ }^{9}$ Cuban agreed and ended the call by saying,

\footnotetext{
* Associate Professor, John Marshall Law School, Atlanta, Georgia. Many thanks to my friend and colleague, Professor Jeffrey A. Van Detta, for reviewing prior drafts of this Article.

1. Harold K. Gordon et al., The SEC's Insider Trading Case Against Mark Cuban and Rule 10b5-2, CORPORATE COUNSEL: LAW.COM (Aug. 3, 2009), http://www.law.com/jsp/cc/PubArticle FriendlyCC.jsp?id=1202432694779.

2. SHARESLEUTH, http://sharesleuth.com/about/ (last visited Dec. 19, 2010).

3. SEC v. Cuban, 634 F. Supp. 2d 713, 717 (N.D. Tex. 2009), vacated, remanded, 620 F.3d 551 (5th Cir. 2010).

4. 15 U.S.C. § $78 \mathrm{j}(\mathrm{b})(2006)$.

5. 17 C.F.R. § 240.10b-5 (2010).

6. Cuban, 634 F. Supp. 2d at 717.

7. Id.

8. Id.

9. Id.
} 
"Well, now I'm screwed. I can't sell." ${ }^{10}$ Yet he did. ${ }^{11}$ Within a minute after hanging up with the CEO, Cuban directed his broker to sell his entire $6.3 \%$ interest. $^{12}$ By selling his stock before public announcement of the PIPE offering, Cuban avoided losses in excess of $\$ 750,000$. $^{13}$

The SEC alleged that Cuban was liable under the misappropriation theory of insider trading. ${ }^{14}$ Because he agreed to keep whatever information the CEO told him confidential and never informed Mamma.com of his intention to sell his stock after learning of the PIPE, Cuban violated a fiduciary duty or similar relationship of trust and confidence he owed to Mamma.com. ${ }^{15}$ The SEC argued that his agreement to keep the information confidential created the necessary relationship which imposed on Cuban a duty to disclose to Mamma.com his intent to trade. ${ }^{16}$ On July 17, 2009, the District Court for the Northern District of Texas dismissed the complaint against Cuban. ${ }^{17}$ Although the court agreed with the SEC that an agreement can form the basis of a duty to disclose, it held that an agreement such as Cuban's must consist of more than a promise to keep the information confidential. ${ }^{18}$ The agreement must consist of a promise not to use the information. ${ }^{19}$ According to the Court, Cuban's agreement with Mamma.com's CEO lacked any obligation to refrain from trading or otherwise using the confidential information. ${ }^{20}$

The district court case against Mark Cuban is another in a line of cases in which defendants who trade using misappropriated confidential information are not held liable for insider trading. ${ }^{21}$ The cases are rather

10. Id.

11. Id. at 718 .

12. Id.

13. Id. The PIPE offering is a way to raise capital but has the effect of diluting existing shareholders' ownership interests, a fact of which Cuban was well aware. Id. at 717. Therefore, once the PIPE offering was announced, Mamma.com's stock price declined. Id. at 718.

14. Id. at $717-18$.

15. Id.

16. Id.

17. Id. at 717 .

18. Id. at $724-26$.

19. Id. at 726 .

20. Id. at 731. The Fifth Circuit recently vacated the district court's judgment, dismissing the case and remanding for further proceedings. SEC v. Cuban, 620 F.3d 551, 558 (5th Cir. 2010). The Fifth Circuit reasoned that a plausible basis existed to find that Mamma.com's CEO and Cuban had an understanding that Cuban would not trade using the information he learned about the PIPE. Id. at 557.

21. See, e.g., SEC v. Talbot, 430 F. Supp. 2d 1029 (C.D. Cal. 2006), rev'd, 530 F.3d 1085 (9th Cir. 2008); United States v. Kim, 184 F. Supp. 2d 1006 (N.D. Cal. 2002); United States v. Cassese, 273 F. Supp. 2d 481 (S.D.N.Y. 2003). 
remarkable, in part because many involve defendants who ought to know better. They are corporate presidents and board members, savvy investors, and, in Cuban's case, a principal in a company that ferrets out securities fraud. From an analytical standpoint, these cases are troubling because of the way in which the fiduciary requirement from Chiarella $v$. United States, ${ }^{22}$ a United States Supreme Court case concerning the misappropriation theory, hampers a finding of liability. ${ }^{23}$

Paradoxically, the fiduciary requirement has its origins in the landmark administrative decision Cady, Roberts \& Co. ${ }^{24}$ There, the SEC determined that the anti-fraud provisions of Rule 10b-5 "are not intended as a specification of particular acts or practices which constitute fraud, but rather are designed to encompass the infinite variety of devices by which undue advantage may be taken of investors and others."25 Certainly, corporate insiders may be liable for failure to disclose "material facts which are known to them by virtue of their position but which are not known to persons with whom they deal."26 But as Rule 10b-5's prohibitions relate to "any person," anyone in possession of material, nonpublic information is under a duty either to abstain from trading on the basis of that information or disclose that information to investors. The SEC determined that an obligation to disclose or abstain arose first from

the existence of a relationship giving access, directly or indirectly, to information intended to be available only for a corporate purpose and not for the personal benefit of anyone, and second, the inherent unfairness involved where a party takes advantage of such information knowing it is unavailable to those with whom he is dealing. ${ }^{27}$

From this case, insider trading became a claim rooted in nonfeasancean omission or failure to do something-as opposed to misfeasanceactively doing an unlawful act. In other words, the defendant may face liability if he failed to disclose material, nonpublic information in

22. 445 U.S. 222, 228 (1980).

23. Other courts, however, have found a fiduciary duty or similar relationship of trust and confidence existed, sometimes in strikingly similar factual scenarios to the cases where other courts held none existed. See, e.g., SEC v. Kirch, 263 F. Supp. 2d 1144, 1150 (N.D. Ill. 2003); SEC v. Kornman, 391 F. Supp. 2d 477, 488-90 (N.D. Tex. 2005).

24. Exchange Act Release No. 6668, 40 SEC Docket 907, 911 (Nov. 8, 1961); see also David Cowan Bayne, The Insider's Natural-Law Duty: Chestman and the 'Misappropriation Theory,' 43 U. KAN. L. REV. 79, 88-89 (1994).

25. Cady, Roberts \& Co., 40 SEC Docket at 911.

26. Id.

27. Id. at 912 (citation omitted). 
violation of a duty to disclose. The fraud, or deception, necessary for Rule 10b-5 liability is this failure to disclose the information to someone to whom you owe a duty.

The Supreme Court in Chiarella refined the Cady, Roberts \& Co. holding insofar as the Court ruled that a defendant is only under a duty to disclose if that defendant is bound by a fiduciary duty or some similar relationship of trust and confidence with those to whom he might owe this duty. ${ }^{28}$ If this special relationship does not exist, the defendant owes no duty to disclose the information and can trade or tip with impunity. Plaintiffs, including the SEC and the United States government, have faced considerable difficulty in certain cases overcoming this relationship requirement, thereby frustrating enforcement efforts. This requirement in such cases can ultimately exempt trades made on inside information by placing the relational aspect of the equation in a paramount position. In doing so, however, the broader enforcement agenda-leveling the playing field of the market and preventing profiteering from trading on inside information - is frustrated.

The characterization of insider trading as fraud by omission has necessitated a finding that some relationship exists sufficient to impose on the trading defendant a duty to disclose. While this construct might work well enough in the context of the classical theory of insider trading, it has frustrated enforcement efforts in the misappropriation context. If a defendant misappropriates material, nonpublic information from another but has no relationship with the other sufficient to impose a duty to disclose his trading intentions, there has been no fraud. Take the case of Mark Cuban. Set aside for a moment the issue of whether Cuban's agreement to maintain the confidentiality of the PIPE offering constitutes an obligation to refrain from using the information. Had there been no agreement whatsoever and Cuban misappropriated news of the offering before its announcement and sold his stock, there would be absolutely no basis for liability. Even though he was the largest Mamma.com shareholder, he had no other relationship with Mamma.com. He owed no fiduciary duty to Mamma.com-he did not sit on its board or act as an executive officer. Yet Cuban is an extremely experienced investor. He is the majority owner of another company whose main purpose is to expose securities fraud. And Cuban knew he was in possession of material, nonpublic information that he could not use for selling his stock. But absent any "special relationship" between Cuban and Mamma.com, all of these facts are irrelevant. Absent a special

28. Chiarella v. United States, 445 U.S. 222, 228 (1980). 
relationship, Cuban's failure to disclose to Mamma.com his intent to sell his stock did not amount to fraud because he was under no duty to disclose those intentions.

Characterizing insider trading as nonfeasance demands this relationship exist to assert liability. And when it does not exist, defendants like Cuban can fall through the cracks. $^{29}$ This relationship requirement has created a gap in the law that allows traders to get away with wrongfully trading on misappropriated information. And arguably, given the roles the defendants play in the corporate landscape, they should know that what they have done is wrong. If insider trading is characterized as misfeasance, however, courts would not need to determine whether a special relationship exists sufficient to impose a duty to disclose. ${ }^{30}$ The trading defendant would be liable for his

29. Professor Donna Nagy anticipated the potential enforcement problems created by the relationship prerequisite in the misappropriation theory as set forth in the Supreme Court's decision in O'Hagan. Donna M. Nagy, Reframing the Misappropriation Theory of Insider Trading Liability: A Post-O’Hagan Suggestion, 59 OHIO ST. L.J. 1223, 1251 (1998). Professor Nagy notes that "O'Hagan endorsed an unnecessarily restrictive misappropriation theory that will likely frustrate the Government's ability in the future to pursue other, more factually complex, instances of securities trading based on misappropriated information.” Id. In so doing, O'Hagan's restrictiveness will make enforcement efforts by the government against both the "non-fiduciary thief" and the "brazen fiduciary" much more difficult. Id. at 1252-58. If there is no relationship between the thief and the source, there may be no liability. Id. at 1252-56. Similarly, if the fiduciary misappropriator discloses his trading intentions to the source, there may likewise be no liability. Id. at 1256-59.

30. In nonfeasance cases generally, absent some special relationship, "one person owes another no duty to take active or affirmative steps for the other's protection. A defendant is generally subject to liability for misfeasance ... but not for nonfeasance.” DAN B. DOBBS \& PAUL T. HAYDEN, TORTS AND COMPENSATION: PERSONAL ACCOUNTABILITY AND SOCIAL RESPONSIBILITY FOR INJURY 483 (5th ed. 2005); see also RESTATEMENT (SECOND) OF TORTS § 314 (1966); DAN B. DOBBS, THE LAW OF TORTS 853 (2000). The general rule is that "[u]nless the defendant has assumed a duty to act, or stands in a special relationship to the plaintiff, defendants are not liable in tort for a pure failure to act for the plaintiff's benefit.” DOBBS, supra, § 314, at 853. Although insider trading claims are not negligence claims, the original construct of the claim as set forth by SEC Chairman Cary in Cady, Roberts \& Co. implicitly identified as relevant the elements of common law deceit, as well as the elements of a negligence action, in determining to whom a duty to disclose might flow. Bayne, supra note 24, at 95-96. "The fact that the defendant foresees harm to a particular individual from his failure to act does not change the general rule.” DoBBS, supra, § 314, at 853. Thus, for example, one will not be liable to another when he fails to save her from drowning, but he will be liable for failing to rescue her if he was the one who pushed her into the water. Because the defendant affirmatively acted, the law imposes on him a duty to protect. While the duty to protect in the misfeasance-nonfeasance tort context is theoretically different from a duty not to use or profit from wrongfully acquired confidential information, the two are more alike in the insider trading context than might appear at first glance. Professor Bayne argued that the "possessor of inside information has a [d]uty to [p]rotect any [s]hareholder from certain injury resultant on nondisclosure." David Cowan Bayne, Insider Trading: The Essence of the Insider's Duty, 41 U. KAN. L. REV. 315, 320 (1992) (emphasis omitted). As the unknowing investor is "'wholly unprotected from the misuse of special information,"” the misappropriator has a duty to protect those investors by disclosing misappropriated information. Bayne, supra note 24, at 88-89. In a misfeasance context, a misappropriator has a similar duty to protect by way of not using misappropriated information for 
unlawful use of the information, not his failure to disclose it. This Article examines the enforcement gap created by applying the relationship requirement to misappropriation cases as nonfeasance, rather than misfeasance.

Part II of this Article describes the evolution of courts' treatment of this fiduciary, or "fiduciary-like," requirement, which created this enforcement gap. Part III identifies how this gap has manifested itself in recent failed insider trading enforcement efforts. Part III discusses recent insider trading cases brought under the misappropriation theory in which no liability was imposed on the most sentient of wrongdoers because the courts in those cases found that no duty existed on the part of the wrongdoers to disclose the information to which they were privy. The courts' reliance on a fiduciary relationship or "similar relationship of trust and confidence" 31 has allowed certain individuals to escape liability where, arguably, liability would have been appropriate. ${ }^{32}$ This reliance has led to increasingly erroneous results-results which appear completely at odds with the aim of the federal securities laws which prohibit insider trading. ${ }^{33}$ Part IV of this Article illustrates how classifying misappropriation claims as misfeasance would work to fill this gap, either as a supplemental theory of liability to the classical and misappropriation theories, or perhaps to supplant them both. Part IV identifies how misfeasance amounts to deception necessary for an insider trading claim. It also discusses how the scienter requirement is satisfied in this context. Finally, it addresses the validity of a misfeasance characterization given the analytical compromises created by the Supreme Court in United States v. O'Hagan. ${ }^{34}$ In short, by casting insider trading as misfeasance, the hope is to increase predictability and

personal gain. When a defendant engages in misfeasance, there is no need to identify some relationship or other action taken sufficient to impose that duty. See RESTATEMENT (SECOND) OF TORTs § 314; DOBBS, supra, § 314, at 854.

31. United States v. Chestman, 947 F.2d 551, 564 (2d Cir. 1991).

32. SEC v. Talbot, 430 F. Supp. 2d 1029, 1065 (C.D. Cal. 2006), rev'd, 530 F.3d 1085 (9th Cir. 2008); United States v. Kim, 184 F. Supp. 2d 1006, 1012 (N.D. Cal. 2002); United States v. Cassese, 273 F. Supp. 2d 481, 486 (S.D. N.Y. 2003).

33. According to the SEC, "[b]ecause insider trading undermines investor confidence in the fairness and integrity of the securities markets, the SEC has treated the detection and prosecution of insider trading violations as one of its enforcement priorities.” Insider Trading, U.S. SECURITIES AND EXCHANGE COMMISSION, http://www.sec.gov/answers/insider.htm (last visited Dec. 19, 2010). As a result, the SEC has instituted a massive and sweeping program to seek civil or criminal liability for almost any suspected insider trading and would desire to impose liability on every violator of the insider trading laws. Thomas C. Newkirk \& Melissa A. Robertson, Speech by SEC Staff: Insider Trading-A U.S. Perspective (Sept. 19, 1998), http://www.sec.gov/news/speech/speecharchive/1998/ spch221.htm.

34. 521 U.S. 642 (1997). 
uniformity in these cases from an analytical standpoint. Moreover, classifying insider trading as misfeasance may increase the reluctance of either the fiduciary misappropriator, who discloses his trading intentions to the source, or the converter of information, who has no relationship to the source, ${ }^{35}$ from taking others' confidential information and using it for their own personal benefit, thereby benefitting the broader enforcement agenda.

\section{THE FIDUCIARY DUTY OR "SIMILAR RELATIONSHIP OF TRUST AND CONFIDENCE” REQUIREMENT AND THE CREATION OF THE ENFORCEMENT GAP: CADY, ROBERTS \& CO. AND ITS PROGENY}

Rule 10b-5 was drafted in 1942 after the SEC received a report that the president of a company was making pessimistic public statements about the company. ${ }^{36}$ As shareholders dumped their stock due to the negative information, he bought the stock at a price lower than it otherwise would have been but for his statements. ${ }^{37}$ The SEC sought to attack this transaction as a violation of the securities laws, so it drafted Rule 10b-5. ${ }^{38}$ After very little discussion other than a comment by SEC Commissioner Sumner Pike-“'“Well,' he said, 'we are against fraud, aren't we?'”- -Rule 10b-5 was adopted. ${ }^{39}$ Although Rule 10b-5 does not specifically address insider trading per se, it does prohibit fraud in the context of buying or selling any security. ${ }^{40}$

Much of the complexity with which the misappropriation theory is fraught has its origins in the administrative decision in Cady, Roberts \& $\mathrm{Co}^{41}$ In its decision, the SEC discussed not only the duties of an outsider turned constructive insider ${ }^{42}$ but also laid the foundation for the requirement of a fiduciary duty or similar relationship of trust and

\footnotetext{
35. Professor Nagy identified the likely culprits who would slip through the cracks as the "brazen fiduciary" and the "non-fiduciary thief." Nagy, supra note 29, at 1252, 1256. 15.

36. See Milton V. Freeman, 'Insider Trading' v. 'Unfair Use,' NAT’L L.J., June 13, 1983, at 15,

37. See id.; see also Ernst \& Ernst v. Hochfelder, 425 U.S. 185, 212 n.32 (1976).

38. Ernst \& Ernst, 425 U.S. at 212 n.32.

39. See Louis Loss, Fundamentals of Securities Regulation 821 (3d ed. 1983) (quoting Milton V. Freeman, General Discussion, Conference on Codification of the Federal Securities Laws, 22 Bus. LAW. 793, 921-23 (1967)); see also Ernst \& Ernst, 425 U.S. at 212-13 n.32.

40. 17 C.F.R. § 240.10b-5 (2010).

41. Exchange Act Release No. 6668, 40 SEC Docket 907 (Nov. 8, 1961).

42. According to the SEC's opinion, certain groups have "a special relationship with a company and are privy to its internal affairs, and thereby suffer correlative duties in trading in securities." Id. at 912. Such groups include a company’s accountants, bankers or lawyers. Id.
} 
confidence. The Cady, Roberts \& Co. decision first highlighted the fact that insiders have an obligation to disclose material facts, "which are known to them by virtue of their position but which are not known to persons with whom they deal and which, if known, would affect their investment judgment." 43 However, as section 10(b) and Rule 10b-5 relate to "any person," this obligation will be imposed on noninsiders as well, assuming two principal elements are met: (1) a relationship that affords access to corporate information and (2) the inherent unfairness that exists when such person takes advantage of the information knowing it is unavailable to those with whom he is dealing. ${ }^{44}$ Thus, the SEC found that Gintel, a securities broker, violated section 10(b) and Rule 10b-5 when he sold shares of Curtiss-Wright Corp. held in his customers' discretionary accounts after being informed by a director of Curtiss-Wright-who was also a member of Gintel's firm-that CurtissWright intended to declare a dividend to its stockholders at a reduced amount than prior dividend distributions. ${ }^{45}$ As a result, members of the buying public were harmed when they bought shares of Curtiss-Wright without knowing the dividend to be paid on those shares would be less per share than it had been in the past. ${ }^{46}$

The SEC reasoned that because Gintel was privy to confidential information before Curtiss-Wright made it public, he should bear the same obligation of disclosure as an insider would. ${ }^{47}$ The court reasoned that Gintel's violation of Rule 10b-5 extended a remedy to members of the investing public, as well as existing stockholders. ${ }^{48}$ Because the federal securities laws exist to protect the buying public from the misuse of confidential information, the court deemed liability appropriate. ${ }^{49}$ Thus, the SEC's interpretation of section 10(b) and Rule 10b-5 was that anyone privy to private corporate information, either directly or indirectly, had an obligation to any member of the investing public either

\footnotetext{
43. Id. at 911.

44. Id. at 912. The SEC further reasoned:

In considering these elements under the broad language of the anti-fraud provisions we are not to be circumscribed by fine distinctions and rigid classifications. Thus, our task here is to identify those persons who are in a special relationship with a company and privy to its internal affairs, and thereby suffer correlative duties in trading in its securities. Intimacy demands restraint lest the uninformed be exploited.

45. Id. at $910-12$.

46. See id. at 913 (holding that Gintel's conduct constituted fraud or deceit upon the purchasers of the stocks).

47. Id. at 912 .

48. See id. at 913-14.

49. Id.
}

Id. 
to disclose such information before purchasing or selling securities of the company or simply abstain from engaging in the transaction. ${ }^{50}$ This has become known as the "disclose or abstain" rule.

Until Chiarella was decided, the SEC and the Second Circuit imposed this duty to disclose on anyone in possession of material, nonpublic information. ${ }^{51}$ For example, in SEC v. Texas Gulf Sulphur Co., the Second Circuit interpreted the language from the SEC's Cady, Roberts \& Co. decision to impose this obligation on "anyone" as dictated by section 10 (b) ${ }^{52}$ The court identified Rule $10 \mathrm{~b}-5$ as implementing the Congressional objective of providing all investors "equal access to the rewards of participation in securities transactions."

The essence of the Rule is that anyone who, trading for his own account in the securities of a corporation has "access, directly or indirectly, to information intended to be available only for a corporate purpose and not for the personal benefit of anyone" may not take "advantage of such information knowing it is unavailable to those with whom he is dealing," i.e., the investing public. ${ }^{54}$

Indeed, the Second Circuit relied on its equal access rationale from Texas Gulf Sulphur in upholding Vincent Chiarella's conviction in United States v. Chiarella. ${ }^{55}$ The Second Circuit reasoned that "[a]nyone corporate insider or not who regularly receives material nonpublic information may not use that information to trade in securities without incurring an affirmative duty to disclose." ${ }^{56}$ Thus, the court imposed an obligation to disclose based on the individual's access to information. Yet the Supreme Court in Chiarella v. United States rejected the imposition of a duty upon anyone who possesses material, nonpublic information to all market participants. ${ }^{57}$ Instead, the Supreme Court held that fraud exists by nondisclosure only when a fiduciary relationship

50. Id. at 912 .

51. See Shapiro v. Merrill Lynch, Pierce, Fenner \& Smith, Inc., 495 F.2d 228, 231 (2d Cir. 1974) (imposing a duty to disclose or abstain on both tippers and tippees on the basis of the equal access rule); Crane Co. v. Westinghouse Air Brake Co., 419 F.2d 787, 794 (2d Cir. 1969); Investors Mgmt. Co., Exchange Act Release No. 9267, 44 SEC Docket 633 (imposing liability against outsiders who had reason to know they possessed nonpublic information).

52. 401 F.2d 833, 848 (2d Cir. 1968).

53. Id. at $851-52$.

54. Id. at 848 (quoting Cady, Roberts \& Co., 40 SEC Docket at 912).

55. 588 F.2d 1358, 1365 (2d Cir. 1978), rev'd, Chiarella v. United States, 445 U.S. 222 (1980).

56. Id.

57. 445 U.S. 222, 231-33 (1980). 
exists between the two parties or a similar relationship of trust and confidence. $^{58}$

Vincent Chiarella was a "markup man" at a financial printer. ${ }^{59} \mathrm{He}$ helped prepare documentation relating to the takeover of five different companies. ${ }^{60}$ Although the identities of the companies were concealed by blanks or false names, he was able to determine their true identities before the final printing of the documents, at which time the actual names would be inserted. ${ }^{61}$ Without disclosing this knowledge to anyone, Chiarella purchased stock in each of the five takeover targets and sold the stock immediately after public announcement of the takeovers, realizing a profit of roughly $\$ 30,000 .^{62}$

The issue before the Court was the legal effect of Chiarella's silence; in other words, when does one have a duty to disclose material, nonpublic information? ${ }^{63}$ The Court began its analysis by recognizing the relationship emphasized in Cady, Roberts \& Co., which gives rise to a duty to disclose by an outsider: one which affords access to material information. ${ }^{64}$ The Court, however, lapsed into a discussion emphasizing that the

duty to disclose arises when one party has information "that the other [party] is entitled to know because of a fiduciary or other similar relation of trust and confidence between"... the shareholders of a corporation and those insiders who have obtained confidential information by reason of their position with that corporation. ${ }^{65}$

The Court then analyzed whether Chiarella had a duty to disclose the information he learned but did so in the context of the duty imposed on insiders of a corporation - a fiduciary duty or similar relationship of trust and confidence to the shareholders of the company. ${ }^{66}$ In other words, while the Cady, Roberts \& Co. decision emphasized a relationship that affords the outsider access to confidential company information, the Court in Chiarella emphasized the relationship between the trader and
58. Id. at 230 .
59. Id. at 224 .
60. Id.
61. Id.
62. Id.
63. Id. at 226 .
64. Id. at 226-27.
65. Id. at 228 (quoting RESTATEMENT (SECOND) OF TORTS § 551(2)(a) (1976)).
66. Id. at 232-33. 
the company's shareholders and whether any fiduciary-type duties exist inherent in that relationship. ${ }^{67}$

The Court determined that no duty to disclose existed by virtue of Chiarella's relationship with the shareholders of the target companies because, in effect, he had no relationship with them; he had no prior dealings with them and was not their agent or fiduciary. ${ }^{68}$ Rather, he simply was a stranger. ${ }^{69}$ To find a duty to disclose existed, the Court reasoned that it would have to recognize a general duty between all market participants to abstain from transactions on the basis of material, nonpublic information. ${ }^{70}$ This was one of the bases upon which the Court rejected the equal access theory recognized in Texas Gulf Sulphur. ${ }^{71}$ The other ground for rejection was that not every instance of financial unfairness is fraudulent. ${ }^{72}$ In other words, the Court recognized that although certain buyers and sellers may have an unfair advantage over less informed investors, that alone does not amount to fraud. ${ }^{73}$ Thus, Chiarella found that "[w]hen an allegation of fraud is based upon nondisclosure, there can be no fraud absent a duty to speak."74 The Court held "that a duty to disclose under section 10(b) does not arise from the mere possession of nonpublic market information., ${ }^{, 75}$

This portion of the opinion sets the stage for the inevitable enforcement gap we experience today. First, the Court made no distinction between corporate insiders and outsiders. It is difficult to conceive of a situation where a true outsider (as opposed to an outsider determined to be a "constructive" insider) would owe a duty to disclose confidential information to a corporation's shareholders before trading on the basis of that information. Stemming from that obstacle, the Court failed to appreciate any middle ground between a fiduciary duty on the one hand and a general duty among all market participants on the other, such as the standard set forth by the SEC in its Cady, Roberts \& Co. decision. As a result, the Court's rationale constructed significant boundaries for enforcement of insider trading claims against anyone

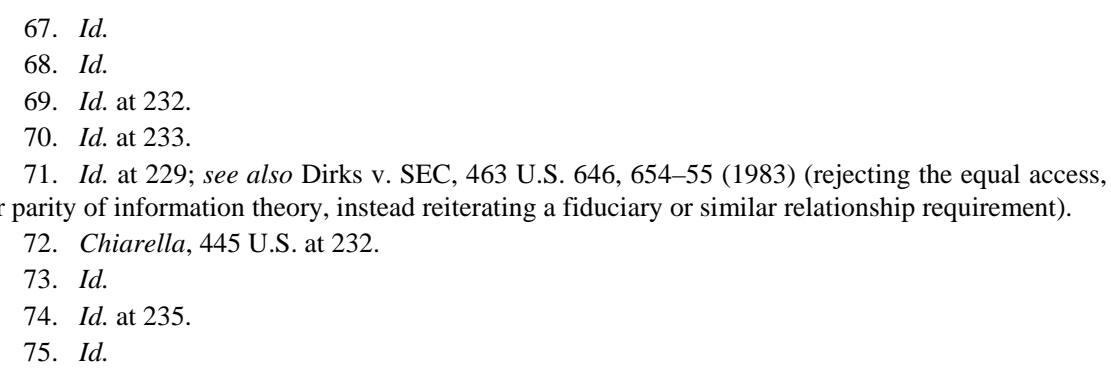


other than a true insider because of its focus on the fraudulent omission-one for which a duty to disclose needs to be imposed under only the proper circumstances. The Court refused to impose this duty on all market participants. Rather, a particular relationship must exist to impose it. Finally, although the Court failed to decide the validity of the misappropriation theory, for it determined it was not properly presented to the jury, its fiduciary relationship requirement became the analytical building block of the misappropriation analysis in United States $v$. O’Hagan. $^{76}$

After twenty or more years of debate among the lower federal courts, ${ }^{77}$ the Supreme Court finally legitimized the misappropriation theory in O'Hagan. ${ }^{78}$ There, the Court determined that O'Hagan, a partner in the law firm of Dorsey \& Whitney, violated section 10(b) and Rule 10b-5 by trading on material, nonpublic information he had gained from his law firm. ${ }^{79}$ The firm was representing Grand Metropolitan PLC in its tender offer bid for all of the common stock of Pillsbury Company. ${ }^{80}$ O’Hagan was not involved in the transaction but learned of it through his firm's representation of Grand Metropolitan. ${ }^{81}$ Before public announcement of the tender offer, O'Hagan purchased 5000 shares of Pillsbury's common stock, as well as 2500 call options for Pillsbury stock, which gave him the right to purchase additional shares of Pillsbury stock for a specified price. ${ }^{82}$ When Grand Metropolitan announced its tender offer, the price of Pillsbury's stock rose to almost sixty dollars per share. ${ }^{83}$ O'Hagan then sold his stock and the call options, making a profit of more than $\$ 4.3$ million. ${ }^{84}$ Because O’Hagan was not a corporate insider at Pillsbury, the government prosecuted him under the misappropriation theory. ${ }^{85}$ The Court determined that O'Hagan owed his law firm a duty of trust and confidence; as such, his trading in Pillsbury securities without disclosing his trading intentions to

76. 521 U.S. 642 (1997)

77. Compare United States v. O’Hagan, 92 F.3d 612, 613 (8th Cir. 1996), rev'd, 521 U.S. 642, and United States v. Bryan, 58 F.3d 933, 943-44 (4th Cir. 1995), abrogated by O'Hagan, 521 U.S. 642, with SEC v. Cherif, 933 F.2d 403, 408 (7th Cir. 1991), SEC v. Clark, 915 F.2d 439, 442 (9th Cir. 1990), and SEC v. Materia, 745 F.2d 197 (2d Cir. 1984).

78. O’Hagan, 521 U.S. at 650.

79. Id. at $646-49$.

80. Id. at 647 .

81. Id.

82. Id.

83. Id. at 648 .

84. Id.

85. Id. at 653 n.5. 
the firm constituted a deceptive device in contravention of section 10(b) and Rule 10b-5. ${ }^{86}$ O'Hagan "feign[ed] fidelity" to his firm while furthering his own pecuniary gain with the information he misappropriated from the firm. ${ }^{87}$

Although O'Hagan broadens liability to a certain extent by capturing outsiders with disclosure obligations to the source of the misappropriated information, later cases reveal that the relationship requirement O'Hagan inherited from Chiarella allows certain wrongdoers to fall through its net. ${ }^{88}$ By focusing on whether a sufficient relationship exists to impose a duty to disclose, courts are forced to ignore the fact that these defendants knowingly traded on material, nonpublic information ${ }^{89}$ - in other words, that they unlawfully used another's proprietary information for their own pecuniary gain. These individuals negatively affect investors and the policy behind the securities laws just as surely as those with a relationship sufficient to impose a duty. It is this use of the confidential information that threatens those policy concerns and not merely the fact that one has some special relationship that requires disclosure.

When an individual actively does something "wrong," as opposed to failing to do the "right" thing, that individual has engaged in misfeasance. Once the individual has harmed others by active commission of a wrong, a duty is said to exist. ${ }^{90}$ In the case of insider trading, this duty would be a duty to refrain from using or profiting from another's confidential information.

\section{RECENT FAILED ENFORCEMENT EFFORTS AS A RESULT OF THE RELATIONSHIP REQUIREMENT}

Recent insider trading cases involving the misappropriation theory of liability have highlighted that the current standard-based on a fiduciary duty or similar relationship of trust and confidence-by which courts base liability for nondisclosure is unworkable. In each of the following cases, although the courts determined no duty existed and, therefore, no violation of section 10 (b) or Rule $10 \mathrm{~b}-5$ occurred, the defendants were

86. Id. at $652-54$.

87. Id. at 653,655 .

88. See infra Part III.

89. See discussion infra Part III.

90. See Restatement (SECOND) OF TORTS § 322 (1966). An exception to this rule exists when public policy dictates the contrary result, for example, in deciding whether a mother owes her unborn child a duty not to smoke or drink while pregnant. See, e.g., DoBBS, supra note 30, § 289, at 787-88. 
individuals who, because of their positions, or expertise, or both, should be aware of the prohibitions against trading in violation of the securities laws. ${ }^{91}$ These cases fit within certain themes. On the one hand, some courts reject the existence of any fiduciary relationship-and thus reject Rule 10b-5 liability - by relying on the characteristics set forth in United States $v$. Chestman as necessary to assert such a relationship: "superiority, dominance, or control." 92 On the other hand, some courts have determined that even though some hallmarks of a relationship exist, such as an obligation of confidentiality, those characteristics are insufficient to give rise to a duty to disclose. ${ }^{93}$ The district court's decision in SEC v. Cuban, discussed above, is an example of such a case. $^{94}$

Although the Fifth Circuit vacated and remanded the district court's dismissal of the SEC's claim, it did not provide any greater clarity to the issue of whether Cuban owed Mamma.com a duty to disclose his trading intentions or abstain from trading. The court reasoned that Cuban's statement-“Well, now I'm screwed. I can't sell.”-plus his follow-up conversation with the sales representative for the PIPE to get pricing information provide a plausible basis that an understanding existed between Cuban and Mamma.com's CEO that Cuban would not trade on the confidential information learned. ${ }^{95}$ Yet their collective understanding is irrelevant to the question of whether Cuban owed Mamma.com a duty. ${ }^{96}$ Although parties' expectations of confidentiality can be relevant to the determination of a duty, ${ }^{97}$ in Cuban the parties' understandings should play no part in that determination. Per Rule 10b5-2(b)(1), Cuban agreed to maintain the information in confidence. ${ }^{98}$ That alone should

91. See SEC v. Talbot, 430 F. Supp. 2d 1029 (C.D. Cal. 2006), rev’d, 530 F.3d 1085 (9th Cir. 2008); United States v. Cassese, 273 F. Supp. 2d 481 (S.D.N.Y. 2003); United States v. Kim, 184 F. Supp. 2d 1006 (N.D. Cal. 2002).

92. 947 F.2d 551 (2d Cir. 1991). The Second Circuit in Chestman set forth guidelines for determining what constitutes a similar relationship of trust and confidence. Id. at 568 . The relationship at issue must be the "functional equivalent of a fiduciary relationship" and thus requires “'reliance, and de facto control and dominance."” Id. (quoting United States v. Margiotta, 688 F.2d 108, 125 (2d Cir. 1982)). The fiduciary relationship “'exists when confidence is reposed on one side and there is resulting superiority and influence on the other." Id. (quoting Mobil Oil Corp. v. Rubenfeld, 339 N.Y.S.2d 623, 632 (Cir. Ct. 1972), rev’d, 370 N.Y.S.2d 943 (App. Div. 1975)).

93. See, e.g., SEC v. Cuban, 634 F. Supp. 2d 713, 727-28 (N.D. Tex. 2009), vacated, remanded, 620 F.3d 551 (5th Cir. 2010).

94. As in Cuban, courts also question the validity or applicability of Rule 10b5-2 to a particular set of facts. See, e.g., Talbot, 430 F. Supp. 2d at 1061-64.

95. Cuban, 620 F.3d at 557-58.

96. Id. at 558 .

97. See, e.g., SEC v. Kirch, 263 F. Supp. 2d 1144, 1150 (N.D. Ill. 2003).

98. Cuban, 620 F.3d at 555. 
suffice to impose a duty on him. Rule 10b5-2 clearly states that “'a duty of trust or confidence' exists" whenever a person has so agreed to maintain that confidence. ${ }^{99}$ If the agreement exists, the duty exists sufficient to require one to disclose or abstain.

\section{A. United States v. Kim}

In United States v. Kim, Keith Joon Kim, CEO of Granny Goose Foods, Inc., purchased shares of Meridian Data, Inc. stock after learning that Meridian was involved in merger negotiations with a company called Quantum Corp. ${ }^{100}$ Kim was a member of the regional forum of the Young Presidents Organization (YPO), an organization for company presidents under fifty years old, as was the CEO of Meridian. ${ }^{101}$ The forum members left March 1, 1999, for their annual retreat, but the CEO of Meridian could not attend the retreat due to the merger negotiations and authorized the moderator to tell the other members why he could not attend. $^{102} \mathrm{He}$ also asked the moderator to stress to the other members that the information was confidential. ${ }^{103}$ Between March 1 and March 4, 1999, Kim purchased 187,300 shares of Meridian stock. ${ }^{104}$ On March 11, 1999, Meridian publicly announced it had agreed to be acquired by Quantum, and Kim realized a significant profit on his investment. ${ }^{105}$

The government prosecuted Kim under the misappropriation theory of insider trading, that one violates section 10(b) and Rule 10b-5 “'when he misappropriates confidential information for securities trading purposes, in breach of a duty owed to the source of the information.",106 Thus, the court was confronted with the issue of whether a fiduciary relationship or a similar relationship of trust and confidence existed between Kim and the members of the forum such that a "legal duty of confidentiality" existed, a violation of which would give rise to liability. ${ }^{107}$ Because the parties agreed that no fiduciary relationship existed between Kim and the forum members, the court analyzed

99. 17 C.F.R. § 240.10b5-2(b)(1) (2010). Unfortunately, the court declined to address the force of Rule 10b5-2(b)(1) or its validity.

100. 184 F. Supp. 2d 1006, 1008-09 (N.D. Cal. 2002).

101 . Id. at 1008.

102. Id.

103. Id.

104. Id. at 1008-09.

105. Id. at 1009 .

106. Id. (quoting United States v. O’Hagan, 521 U.S. 642, 652 (1997)).

107. Id. 
whether a similar relationship of trust and confidence existed. ${ }^{108}$ Using the rationale set forth in United States v. Chestman, ${ }^{109}$ the court in Kim concluded that the government failed to allege facts establishing superiority, dominance, and control among Kim and the members of the YPO. ${ }^{110}$ As a result, although Kim misappropriated confidential information from the YPO and its members, he owed no duty to any of them to disclose his trading intentions, notwithstanding the emphasis placed on the confidentiality of the merger. ${ }^{111}$ Thus, Kim could not be held liable under the misappropriation theory. ${ }^{112}$

\section{B. United States v. Cassese}

United States v. Cassese is another example where Chestman characteristics played a critical role. ${ }^{113}$ There, Compuware Corp. sent a confidentiality agreement to John Cassese, Chairman and President of Computer Horizons Corp., in connection with the potential acquisition of Computer Horizons by Compuware. ${ }^{114}$ The confidentiality agreement prohibited any Computer Horizons employee from trading securities based on any material, nonpublic information learned in the ongoing acquisition negotiations. ${ }^{115}$ However, neither Cassese nor anyone else at Computer Horizons ever signed the agreement. ${ }^{116}$ Compuware ultimately decided not to acquire Computer Horizons. ${ }^{117}$ Karmanos, Compuware's CEO, telephoned Cassese and advised him that Compuware had decided to acquire a company called Data Processing Resources Corp. (DPRC) instead of Computer Horizons and, as Cassese knew, Compuware had not yet publicly announced the acquisition. ${ }^{118}$ The next day, Cassese purchased 15,000 shares of DPRC at $\$ 13.25$ per share. $^{119}$ Immediately following public announcement of the DPRC acquisition, Cassese sold his DPRC stock for \$23.31 a share, yielding a

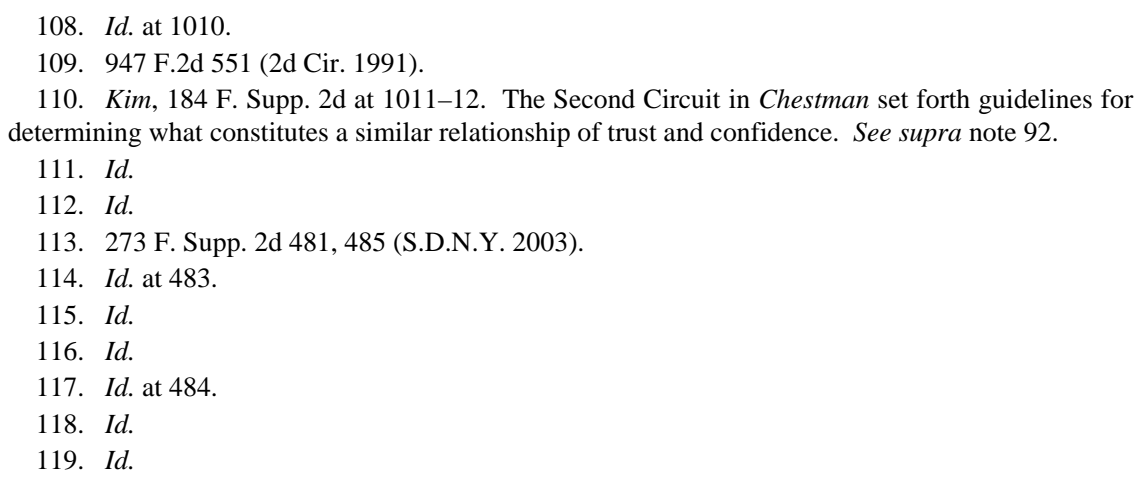


profit of roughly $\$ 151,000 .^{120}$ But because the court determined no relationship existed between Cassese and Karmanos sufficient to impose a duty on Cassese to disclose his trading intentions to Karmanos, the court granted Cassese's motion to dismiss. ${ }^{121}$ Like the court in Kim, the court in Cassese relied on characteristics set forth in Chestman for determining whether a fiduciary or fiduciary-like relationship exists: dominance, disparate knowledge and skill, and confidence reposed by one side with resulting superiority and influence of the other. ${ }^{122}$

C. SEC v. Talbot

Similarly, a court also found J. Thomas Talbot not to have breached a fiduciary duty or similar relationship of trust and confidence when he purchased 10,000 shares of LendingTree after learning of a potential acquisition of LendingTree while at a Fidelity board meeting. ${ }^{123}$ Here, however, the court did not rely on Chestman in making its determination. Instead, the court examined the relationship between Talbot and the source more generally, finding the relationship insufficient to justify any fiduciary analysis. Talbot sat on the board of Fidelity National Financial, Inc.- - a public company whose stock trades on the New York Stock Exchange. ${ }^{124}$ LendingTree's CEO notified Fidelity's Executive Vice President that a third party might acquire LendingTree and asked whether Fidelity would be interested in making an offer to purchase LendingTree. ${ }^{125}$ At the time of this disclosure, Fidelity owned a small percentage of LendingTree stock. ${ }^{126}$ Shortly thereafter, Fidelity held its quarterly board of directors meeting, which Talbot attended. ${ }^{127}$ Toward the end of the meeting, Fidelity's CEO and Chairman, William Foley, told the board of LendingTree's potential acquisition by a third party and stated that Fidelity would likely benefit if the acquisition was consummated. ${ }^{128}$ Two days after the board meeting, on April 24, 2003, Talbot bought 5000 shares of LendingTree stock. ${ }^{129}$ On April 30, 2003,

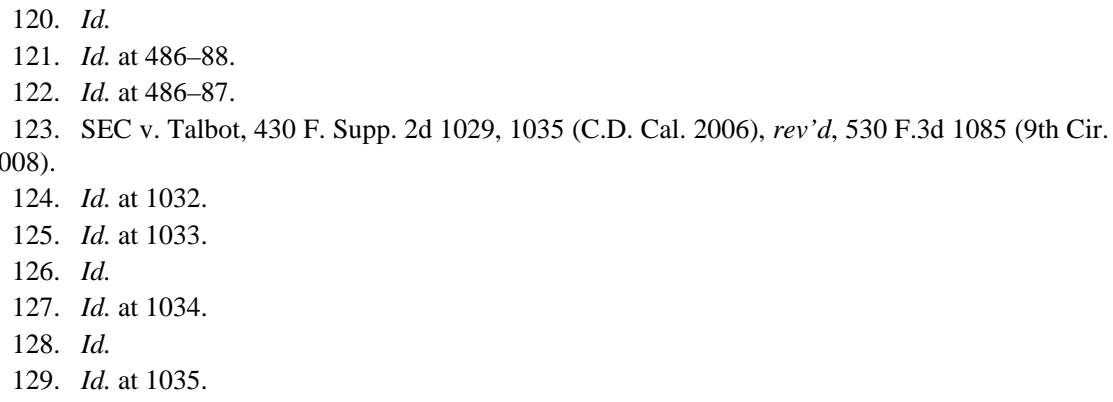


Talbot purchased an additional 5000 shares. ${ }^{130}$ On May 5, 2003, LendingTree's acquisition was made public, and Talbot subsequently sold his 10,000 shares, realizing a profit of roughly $\$ 68,000$. $^{131}$

The court determined that Fidelity, not Foley or LendingTree, was the source of the information. ${ }^{132}$ The court needed to ascertain who the "source" was to determine whether Talbot breached a duty to that source. ${ }^{133}$ Certainly Talbot, as a Fidelity director, owed a duty to Fidelity. General duties notwithstanding, Talbot argued that he owed no duty to Fidelity to maintain the confidentiality of the LendingTree acquisition assuming Fidelity could have traded on the LendingTree information without violating the securities laws. ${ }^{134}$ In other words, "if Fidelity could have traded on the LendingTree information without incurring liability under the securities laws, 'it would be incongruous to find that [he] breached a duty to Fidelity because he received the ... information from ... Fidelity' and traded on it." ${ }^{\text {135 }}$ Because Fidelity was a shareholder of LendingTree, Fidelity did not owe a fiduciary duty of confidentiality to LendingTree; rather, the duty was owed to Fidelity. ${ }^{136}$ And Fidelity did not owe LendingTree a similar relationship of trust and confidence. ${ }^{137}$ As a result, Talbot could not be held liable for insider trading under the misappropriation theory. ${ }^{138}$

Talbot illustrates the circuitous problem created by the fiduciary, or fiduciary-like, relationship that must exist for misappropriation theory liability. Quite rightly, the court determined that Fidelity owed no fiduciary duties to LendingTree. Yet, notwithstanding the lack of any duty to LendingTree, it is patently wrong to suggest that Fidelity should be able to trade in LendingTree stock after having been told information regarding a pending LendingTree acquisition in confidence. Why should Fidelity be allowed to profit from such undisclosed information? Moreover, to suggest a board member can buy or sell stock based on

\footnotetext{
130. Id.

131. Id.

132. Id. at 1048-49. Talbot unsuccessfully argued that Foley was the source of the information and that he was acting outside the scope of his agency for the company when he disclosed the potential acquisition to the Fidelity board. Id. at 1048. The court rejected this argument because communicating information regarding Fidelity's investments and advising the Fidelity board of an event that might impact the company were acts taken within the scope of Foley's agency. Id.

133. Id. at 1046.

134. Id. at 1049.

135. Id.

136. Id. at 1051.

137. Id. at 1064 .

138. Id.
} 
confidential information learned at a board meeting without any securities laws repercussions is inappropriate as well.

The Ninth Circuit reversed and remanded the district court, relying on the fact that Talbot's duty to Fidelity alone sufficed to give rise to liability. ${ }^{139}$ The decision provided meaningful clarity to the existence of a legal duty, insofar as that duty need not be a continuous chain of duties from the originating source, here LendingTree, to the misappropriator. ${ }^{140}$ Notwithstanding this clarity, the case does little for truly determining the existence of a duty in a misappropriation context since the board member-company relationship is such an obvious example of one that dictates fiduciary obligations. ${ }^{141}$

\section{Courts That Have Reached the Opposite Result}

Some courts, however, have held the opposite of those in the cases discussed above, sometimes on almost identical facts. For example, in SEC $v$. Kirch, the court held that Kirch violated the securities laws when he sold his ShowCase Corp. stock after learning that ShowCase would not make its quarterly earnings projections. ${ }^{142}$ Kirch learned this information at a meeting of the CEO Roundtable, a group of key officers of computer software companies that met twice a year to exchange sometimes confidential information about their business and companies. ${ }^{143}$ The Roundtable members had an express policy that they would keep any matters discussed at their meetings confidential. ${ }^{144}$ Kirch sold his stock despite the confidentiality policy and despite being told the information regarding ShowCase was confidential. ${ }^{145}$ The court held that the relationship of the Roundtable members and the recognition

139. SEC v. Talbot, 530 F.3d 1085, 1093 (9th Cir. 2008).

140. Id. at 1093.

141. Moreover, the court's opinion confused another required element of a Rule $10 \mathrm{~b}-5$ claim when it connected the meaning of "confidential" information with the materiality of the information. Id. at 1095-96. As a matter of law, confidential information is information that is not public. Id. at 1095 (citing Hollinger Int'l, Inc. v. Black, 844 A.2d 1022, 1046 (Del. Ch. 2004)). Yet the court associated the confidentiality of the information with the likelihood the transaction at issue would occur and the magnitude of that event. Id. at 1097; see also Basic Inc. v. Levinson, 485 U.S. 224, 238 (1988) (holding that the materiality of speculative events is determined by balancing of both the indicated probability that the event will occur and the anticipated magnitude of the event in light of the totality of the company activity). The confidentiality of information on the one hand, and its materiality on the other, should be kept distinct from one another.

142. 263 F. Supp. 2d 1144, 1153 (N.D. Ill. 2003).

143. Id. at 1147.

144. Id.

145. Id. at 1148. 
that the ShowCase information was confidential called for application of the misappropriation theory. ${ }^{146}$ This result is in stark contrast to the decision reached in Kim. The court rather blithely rejected the defendant's reliance on Kim, stating that it believed the "express confidentiality constraints call for application of the "misappropriation theory' here." ${ }^{\text {"147 }}$ While the court in Kim placed significant importance on what it considered to be the hallmarks of a fiduciary relationshipdominance and control- the court in Kirch believed the expectation of confidentiality sufficed.

Similarly, in SEC v. Kornman, the court held Kornman violated the securities laws when he traded in the securities of both MiniMed Inc. and Hollywood Casino Corp. after learning that each of those companies was to be acquired. ${ }^{148}$ Kornman learned this information after either he or his associates met with executives from those companies to discuss potentially engaging Kornman's company, The Heritage Organization L.L.C., for personal tax advice as a result of the acquisitions. ${ }^{149}$ Although it was Heritage's policy to draft a post-meeting memorandum containing a confidentiality clause, it appears no confidentiality agreement was signed by any party to these discussions. ${ }^{150}$ Regardless of the lack of an executed confidentiality agreement, the court held that Kornman's "superior knowledge as to the subject matter of tax and estate-planning .... serve[d] as an indicator that a duty of trust and confidence had developed between [him] and the two executives."151 Thus, the court relied on Chestman-type characteristics of superiority or dominance in determining a duty did in fact exist. ${ }^{152}$

These cases are troubling for a number of reasons. First, contrasting results in factually similar cases are discouraging. In light of the seriousness with which the SEC advances its enforcement efforts in this area, the need for consistency and uniformity is palpable. Second, while the defendants who escaped liability have not broken the law per se, the wrongfulness of what they did is clear. The individuals in each of the preceding cases hold high-ranking positions in well-developed

\footnotetext{
146. Id. at 1150.

147. Id. at $1150-51$.

148. 391 F. Supp. 2d 477, 480-82 (N.D. Tex. 2005).

149. Id.

150. Id. at $478-80$.

151. Id. at 489. The court relied in large part on the language from Chestman requiring relationships characterized by superiority, dominance, or control and found these criteria existed in Kornman. Id. at 488-89.

152. Id. at $487-88$.
} 
businesses, which suggests they know or should know the implications of their actions. But they got lucky in the face of the analytical gymnastics engaged in by these courts when determining whether a duty exists sufficient to hold them liable for their actions. Each court attempted to determine what obligations these individuals owed the relevant source of the information; and if the relationships between the parties yielded no obligation to maintain confidentiality or disclose trading intentions, then the misappropriators have defrauded no one. While these cases demonstrate that courts wrestle with questions of whether certain expectations exist based on the kind of relationship the parties have, the opinions have created a lack of consistency. While some of these cases rely on evidence of superiority and dominance as between one party to the other, others rely on the expectations of the parties, who may not be unequal to each other. Moreover, the mere fact that a source exists does not make it any easier to determine whether a duty to that source exists. This difficulty yields enforcement disparities regarding what should be uniformly applied federal law.

Is there a way to close this gap in an analytically appropriate manner that follows a textual reading of section 10(b) and Rule 10b-5? As described below, characterizing insider trading as a wrong by commission, as opposed to one of omission, appears to do exactly that. The question taken up in the next Part is whether improper trading alone, absent any relationship conferring a duty, is sufficient to establish the requisite fraud necessary for Rule 10b-5 liability. Because the misappropriation theory relies on "feigning fidelity" to the source by not disclosing one's trading intentions as its requisite deception, perhaps an alternate theory, based on something other than nondisclosure, can serve as the basis for liability in other contexts.

\section{INSIDER TRADING AS MISFEASANCE}

\section{A. Analytical Framework of the Misappropriation Claim}

Insider trading liability is premised upon a violation of section 10(b) of the Securities and Exchange Act of $1934^{153}$ and Rule 10b-5. ${ }^{154}$ Section 10(b) prohibits the use of any manipulative or deceptive device

153. 15 U.S.C. § 78j(b) (2006).

154. 17 C.F.R. § 240.10b-5 (2010). 
or contrivance in connection with the purchase or sale of a security. ${ }^{155}$ Rule 10b-5 provides in pertinent part:

It shall be unlawful for any person, directly or indirectly, ...

(a) To employ any device, scheme, or artifice to defraud, [or] ...

(c) To engage in any act, practice, or course of business which operates or would operate as a fraud or deceit upon any person, in connection with the purchase or sale of any security.

Courts have interpreted a "manipulative" device or contrivance to mean something used to manipulate the securities markets generally, "such as wash sales, matched orders, or rigged prices, that are intended to mislead investors by artificially affecting market activity."157 A "deceptive" device has been identified as either a misrepresentation of material fact or an omission thereof. ${ }^{158}$ Recognition of those concepts as the only manipulative or deceptive devices helped categorize insider trading as an omission claim. ${ }^{159}$ Indeed, the Supreme Court, in its decision in United States $v$. Chiarella, refused to extend the term deception beyond a misrepresentation or a duty to disclose, holding: "When an allegation of fraud is based upon disclosure, there can be no fraud absent a duty to speak ... premised upon a duty to disclose arising from a relationship of trust and confidence between the parties to a

\footnotetext{
155. 15 U.S.C. § 78j. Section 10(b) specifically provides:

It shall be unlawful for any person, directly or indirectly, . . .

157. Santa Fe Indus. v. Green, 430 U.S. 462, 476 (1977); see also Daniel A. McLaughlin, Liability Under Rules 10b-5(a) \& (c), 31 DEL. J. CORP. L. 631, 636 (2006) (“[C]ourts have followed this definition of 'manipulative' as referring to similar types of artificial market activity (i.e., the execution of securities transactions designed to simulate genuine interest in buying or selling at an artificial price).”).

158. See Santa Fe Indus., 430 U.S. at 475-76.

159. See Chiarella v. United States, 445 U.S. 222, 235, 230 (1980); McLaughlin, supra note 157, at 636-37 (noting that the Court in Chiarella refused to extend the concept of deception beyond misrepresentations or omissions).
} 
transaction.” ${ }^{60}$ Because the courts had identified those as the only relevant manipulative or deceptive devices, insider trading needed to fit within that rubric. Under the "classical" theory of insider trading liability, when a corporate insider trades in his company's securities on the basis of the company's material, nonpublic information, without disclosing the information first to shareholders, that trading qualifies as a "deceptive device" under the statute. ${ }^{161}$ Because the insider has a fiduciary relationship with the shareholders of the company, he must disclose the information to the shareholders before purchasing or selling shares of the company on the basis thereof. ${ }^{162}$ Thus, if he purchases or sells securities without disclosing the relevant information to the shareholders, he has deceived or defrauded them because he has failed to disclose when under a duty to do so. Otherwise, the insider would be allowed to take advantage of the uninformed shareholder for his own personal gain. ${ }^{163}$

The requisite deception occurs under the misappropriation theory when "outsiders" of the corporation misappropriate a company's "confidential information for securities trading purposes . . . in breach of a duty owed to the source of the information,"164 rather than to the shareholders of the company. Thus, liability will be imposed when an outsider learns of material, nonpublic information from a "source" to whom he owes a duty-for example, his own employer-and fails to disclose to that source that he intends to trade on the basis of the information. ${ }^{165}$ He has a duty to disclose his trading intentions to the source, the entity from whom he misappropriated the information. ${ }^{166}$

The underlying rationale of the misappropriation theory is that a person who receives secret business information from another because of an established relationship of trust and confidence between them has a duty to keep that information confidential. By breaching that duty and appropriating the confidential information for his own advantage, the fiduciary is defrauding the confider who was entitled to rely on the fiduciary's tacit representation of confidentiality. ${ }^{167}$

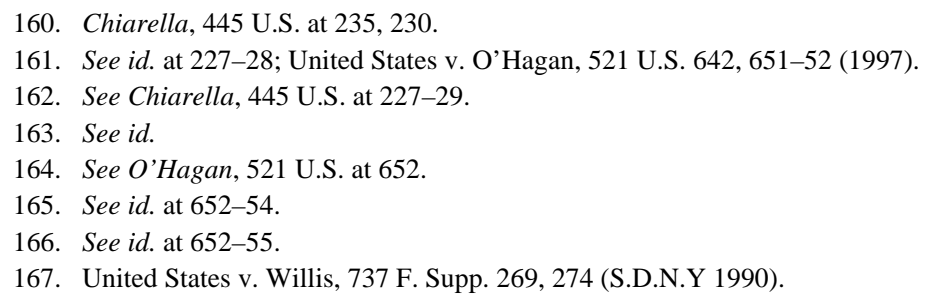


In essence, the deception occurs because the misappropriator-trader should have been more loyal to the source but was not.

\section{B. Rejection of Omission as the Basis for an Insider Trading Claim}

1. Stoneridge and Its Acknowledgment that Conduct Violates Rule 10b-5

Notwithstanding the Supreme Court's earlier pronouncements that manipulations of the market, misrepresentations, or omissions are the only viable means to establish a Rule 10b-5 claim, it altered course somewhat in its decision in Stoneridge Investment Partners v. ScientificAtlanta, Inc. ${ }^{168}$ In the context of whether a scheme to defraud could provide the basis for Rule 10b-5 liability, the Court made clear that conduct - in addition to a misrepresentation or omission-may also violate section 10(b). ${ }^{169}$ This assertion is extremely important in an insider trading context. It presents an opportunity to frame an insider trading claim as something other than an omission for which a duty to disclose must exist. In other words, it could allow for characterization of insider trading as misfeasance-the unlawful use of material, nonpublic information. This standard is very different from what the Court in Chiarella insisted was necessary for Rule 10b-5 liability-that because insider trading was fraud based on nondisclosure (nonfeasance), it is actionable only when there exists a duty to speak. If an insider trading claim can be revisited in the context of actionable conduct, the possibility exists to frame the claim as one of misfeasance-the unlawful use of information for one's own personal benefit.

\section{The Waning Fiduciary Relationship}

Another development which lends credence to insider trading as misfeasance is the waning importance of the fiduciary relationship, both in the corporate context generally, as well as in the insider trading context. ${ }^{170}$ It has been recently argued that, to the extent insiders owe

168. 552 U.S. 148 (2008).

169. See id. at 158 (stating that conduct can also be deceptive and thus violate section 10(b)); Cent. Bank of Denver v. First Interstate Bank of Denver, 511 U.S. 164, 177 (1994) (stating that section 10(b) prohibits not only the making of a misstatement or omission but also the commission of a manipulative act).

170. See Kelli A. Alces, Debunking the Corporate Fiduciary Myth, 35 J. CORP. L. 239, 258-59 (2009); Donna M. Nagy, Insider Trading and the Gradual Demise of Fiduciary Principles, 94 IowA 
any fiduciary duties, they do not owe them to shareholders, but rather to the corporation, however that entity is defined. ${ }^{171}$ The belief that directors and executive officers owe shareholders fiduciary duties, and duties of disclosure specifically, stems from the traditional view that shareholders own the corporation due to initial capital contributions and their status as residual claimants. ${ }^{172}$ This assertion necessarily implies that the insiders would not owe such duties to other investors such as creditors. ${ }^{173}$ Yet in many instances, capital provided by creditors constitutes a significant portion of the capitalization in a particular corporation. ${ }^{174}$ Unsurprisingly, the creditors have protected themselves and their capital by contractually requiring certain obligations from insiders. ${ }^{175}$ Thus, an emerging idea is that the historical view of fiduciary obligations owed to shareholders should give way to negotiated obligations in a contractual setting. ${ }^{176}$ Taking the idea that corporate insiders might not owe shareholders a fiduciary duty would support the

L. REV. 1315, 1340-52 (2009).

171. See Alces, supra note 170, at 245-48; Douglas G. Baird \& M. Todd Henderson, Other People's Money, 60 StAN. L. ReV. 1309, 1310-13, 1333 (2008); Margaret M. Blair \& Lynn A. Stout, A Team Production Theory of Corporate Law, 85 VA. L. REV. 247, 300-01 (1999).

172. See Alces, supra note 170, at 247. Yet at the same time, the board does many things that favor creditors and other investors at the expense of shareholders, like, for example, filing a bankruptcy petition. Baird \& Henderson, supra note 171, at 1316. Other examples include structuring a merger to eliminate shareholder vote, removing rights of appraisal, and buying out minority shareholders at the request of a majority shareholder. Id. at 1317-18.

173. Baird \& Henderson, supra note 171, at 1333. Professor Alces observes:

All of those facts about the state of shareholders' relationship to management ... conflict with traditional understandings of enforceable fiduciary duties. For example, a beneficiary of fiduciary duties can hold the fiduciary liable for preferring the interests of others above his own and can require that the fiduciary not act contrary to the beneficiary's interests at all, particularly not for the benefit of a party to whom fiduciary duties are not owed.

Alces, supra note 170, at 246.

174. See Baird \& Henderson, supra note 171, at 1310-11.

175. See id. at 1311.

176. Alces, supra note 170, at 258-59; Baird \& Henderson, supra note 171, at 1333-42. Professor Alces notes:

If we acknowledge that shareholders are not beneficiaries of particular fiduciary duties and question whether they are really "owners" of a firm, then we must see that we have moved beyond the traditional understanding of corporate fiduciary duties. Directors are not fiduciaries of the shareholders. While what is good for the residual claim is often good for corporate wealth maximization, common goals alone do not give rise to a fiduciary relationship. Fiduciary relationships require a clear beneficiary who can enforce certain obligations of loyalty, that is, a beneficiary who can insist that its interests are preferred above all others and are the singular focus of the fiduciary's efforts on the beneficiary's behalf. In our ever-changing and increasingly complex corporate world, directors and officers simply do not act "on behalf" of shareholders. Rather, their duty, to the extent fiduciary, seems to be owed to the corporation.

Alces, supra note 170, at 247. 
idea that liability for insider trading is not properly established atop that foundation. ${ }^{177}$

Moreover, recent history has witnessed a shift away from strict adherence to relationships which qualify as fiduciary, or fiduciary-like, in the insider trading context. As discussed above, the Court in Chiarella identified "“a fiduciary or other similar relation of trust and confidence"” as the necessary relationship that must exist to impose a duty to disclose. ${ }^{178}$ While a fiduciary relationship may be simple to define, courts have endeavored to adequately define what other relationships might fall within these confines. ${ }^{179}$ In the context of classical insider trading, the Supreme Court in Dirks v. SEC discussed that outsiders become fiduciaries to a corporation's shareholders when they have entered into a "special confidential relationship" with the corporation, whereby they are given access to information solely for corporate purposes and the corporation expects the outsider to keep the information confidential. $^{180}$ Thus, a duty to disclose would be imposed on underwriters, lawyers, accountants, or consultants who are legitimately given access to this kind of information. ${ }^{181}$

In the misappropriation context, the focus is on the relationship between the misappropriator and the source of the confidential information, as opposed to a corporation's shareholders. And although the court in Chestman posited that "fiduciary duties are circumscribed with some clarity in the context of shareholder relations," it recognized that they "lack definition in other contexts."182 Against this backdrop, the court in Chestman set forth criteria noted above for determining when a relationship is fiduciary-like in nature: "'reliance, and de facto control and dominance,","183 “" when confidence is reposed on one side and there is resulting superiority and influence on the other," ${ }^{\prime 184}$ and

177. See Nagy, supra note 170, at 1320. Professor Nagy points out that "numerous lower courts and the SEC have in effect concluded that the wrongful use of information constitutes the crux of the insider trading offense and that fiduciary principles are only relevant insofar as they establish such wrongful use." Id.

178. Chiarella v. United States, 445 U.S. 222, 228 (1980) (quoting RESTATEMENT (SECOND) OF TORTS § 551(2)(a) (1976)).

179. See Dirks v. SEC, 463 U.S. 646, 655 n.14 (1983); supra Part III.

180. Dirks, 463 U.S. at 655 n.14.

181. Id.

182. United States v. Chestman, 947 F.2d 551, 567 (2d Cir. 1991). "Tethered to the field of shareholder relations, fiduciary obligations arise within a narrow, principled sphere. The existence of fiduciary duties in other common law settings, however, is anything but clear.” Id.

183. Id. at 568 (quoting United States v. Margiotta, 688 F.2d 108, 125 (2d Cir. 1982)).

184. Id. (quoting Mobil Oil Corp. v. Rubenfield, 339 N.Y.S. 2d 623 (Civ. Ct. 1972)). 
"discretionary authority and dependency."185 Thus, the court would require some relationship steeped in these characteristics before finding a similar relationship of trust and confidence existed between misappropriator and source. Because the marital relationship at issue in Chestman did not exhibit any of these criteria, notwithstanding the fact the husband promised his wife he would keep the information she told him confidential, the court found the husband not liable for insider trading. ${ }^{186}$

In response to cases like Chestman, the SEC adopted Rule 10b5-2 in 2000 to provide a bright-line rule for determining when certain relationships create duties of trust or confidence. ${ }^{187}$ The Rule sets forth a nonexclusive list of situations that create these duties. ${ }^{188}$ The Rule was designed "to protect investors and the fairness and integrity of the nation's securities markets against improper trading on the basis of inside information" 189 and to rectify the anomalous result that a "family member who trades in breach of a reasonable expectation of

185. Id. at 569 .

186. Id.

187. 17 C.F.R. § 240.10b5-2 (2010); Selective Disclosure and Insider Trading, 65 Fed. Reg. 51,716 (Aug. 24, 2000) (codified at 17 C.F.R pt. 240). Professor Nagy notes that the change from the conjunctive duty of trust and confidence to the disjunctive duty of trust or confidence considerably extends the scope of the misappropriation theory. Nagy, supra note 170, at 1360 . " $[T]$ he terms 'trust' and 'confidence' are often used synonymously to describe reliance on the character or ability of someone to act in a right and proper way. But as used in Rule 10b5-2, the term 'confidence' may align more with an obligation of 'confidentiality' than with obligations predicated on trust and loyalty." Id. Thus, Rule 10b5-2(b)(1), which covers situations where one "'agrees to maintain information in confidence,"” removes fiduciary principles altogether. Id. at 1361 (quoting 17 C.F.R. § 240.10b5-2(b)(1)).

188. 17 C.F.R. § $240.10 b 5-2(b)$. Subsection (b) of the Rule provides that a duty of trust or confidence exists:

(1) Whenever a person agrees to maintain information in confidence;

(2) Whenever the person communicating the material nonpublic information and the person to whom it is communicated have a history, pattern, or practice of sharing confidences, such that the recipient of the information knows or reasonably should know that the person communicating the material nonpublic information expects that the recipient will maintain its confidentiality; or

(3) Whenever a person receives or obtains material nonpublic information from his or her spouse, parent, child, or sibling; provided, however, that the person receiving or obtaining the information may demonstrate that no duty of trust or confidence existed with respect to the information, by establishing that he or she neither knew nor reasonably should have known that the person who was the source of the information expected that the person would keep the information confidential, because of the parties' history, pattern, or practice of sharing and maintaining confidences, and because there Id. was no agreement or understanding to maintain the confidentiality of the information.

189. Selective Disclosure and Insider Trading, 65 Fed. Reg. at 51,729. 
confidentiality ... does not necessarily violate Rule 10b-5.”"190 The Rule retreats from the more rigid characterizations that earlier typified a necessary fiduciary-like relationship. Now, for example, the imposition of a duty to disclose follows from an agreement of confidentiality between equals in an arms-length transaction ${ }^{191}$ or simply between family members exchanging information. These relationships bear none of the hallmarks of the traditional fiduciary, or fiduciary-like, obligation which carried with it recognition that a fiduciary should not benefit at the expense of the beneficiary.

The First Circuit's recent decision in SEC v. Rocklage is an example of a case where a duty was found under Rule 10b5-2 and thus a corresponding waning of the importance of the fiduciary, or fiduciarylike, relationship as a necessary prerequisite to an insider trading claim. ${ }^{192}$ In Rocklage, a CEO shared with his wife negative, nonpublic information that the company's drug failed a clinical drug trial. ${ }^{193} \mathrm{He}$ also told her that when the market heard the news, the company's stock price was certain to plummet. ${ }^{194}$ Although the CEO emphasized the confidential nature of the information, his wife had a standing agreement with her brother to tell him any negative information she learned from her husband before it became public. ${ }^{195}$ However, before telling her brother, she disclosed her intentions to her husband. ${ }^{196}$ The court, finding the wife liable, determined that she had deceived her husband, notwithstanding her disclosure to her husband, by acquiring the information from him in the first place without telling him she had a standing agreement with her brother. ${ }^{197}$

190. Id.

191. Professor Alces points out that calling a relationship "fiduciary" signals that the fiduciary is held to a higher standard of trust and obligation in serving the beneficiary's interest than otherwise would exist. Alces, supra note 170, at 244. Contractual relationships, on the other hand,

are governed by precise terms and a comparatively low standard of good faith and fair dealing. There is a limit to the extent to which parties in a contractual relationship can take advantage of each other or their relative positions, and they are expected to try, in good faith, to honor their contractual obligations, but remedies for disappointing performance are limited by the terms of the contract and to appropriate and measurable Id. damages.

192. 470 F.3d 1 (1st Cir. 2006).

193. Id. at 3.

194. Id. at 4.

195. Id. at 3-4.

196. Id. at 4 .

197. Id. at 8. 
Notwithstanding the adoption of Rule 10b5-2, the SEC is pushingand courts are recognizing - that fraud can exist in an insider trading claim without any fiduciary duty or similar relationship present. ${ }^{198}$ In SEC v. Dorozhko, for example, the SEC maintained that the defendant's fraud consisted of his alleged computer hacking to gain access to a company's earnings report, rather than any failure to disclose. ${ }^{199}$ The Second Circuit held in Dorozhko that none of the Supreme Court opinions in Chiarella, O'Hagan, or SEC v. Zandford ${ }^{200}$ requires a fiduciary relationship as an element of an actionable securities claim under section 10(b). ${ }^{201}$ While the above cases all stand for the proposition that nondisclosure in breach of a duty to disclose satisfies the deception requirement, the Second Circuit recognized that none of them requires such a relationship to state a claim. ${ }^{202}$ "While Chiarella, O'Hagan, and Zandford all dealt with fraud qua silence, an affirmative misrepresentation is a distinct species of fraud." ${ }^{203}$ Although the court in Dorozhko acknowledged that computer hacking can be a deceptive device sufficient for Rule 10b-5 liability, it remanded the case to determine whether the hacker actually misrepresented his identity to gain

198. SEC v. Dorozhko, 574 F.3d 42, 48 (2d Cir. 2009); SEC v. Blue Bottle Ltd., Exchange Act Release No. 20018, 90 SEC Docket 268 (Feb. 26, 2007) (awarding temporary restraining order against defendants from violating antifraud provisions of securities laws due to fraudulent hacking into companies' computer systems and trading before announcement of those companies' news releases); SEC v. Lohmus Haavel \& Viisemann, No. 05 CV 9259, 2005 WL 3309748 (S.D.N.Y. Nov. 8, 2005) (awarding injunctive relief for defendant's fraudulent hacking into companies' computer systems and trading prior to release of confidential information).

199. 574 F.3d at $44-45$.

200. SEC v. Zandford, 535 U.S. 813 (2002). Zandford dealt with a securities broker who convinced an elderly, infirm man and his mentally retarded daughter to open a joint account with him. Id. at 815. They granted him discretion to manage the account without prior approval. Id. He wrote checks and sold securities from their account and deposited the proceeds therefrom into his own accounts. Id. at 815-16. Even though the Court reasoned that the SEC's complaint described a fraudulent scheme where a securities transaction and breach of fiduciary duty coincide, nowhere does the opinion require that a fiduciary duty exist. See id. at 825 .

201. Dorozhko, 574 F.3d at 48-50. The court held that the defendant computer hacker, who was neither a corporate insider nor had a special relationship with the source of the information, may have committed fraud, notwithstanding the lack of a duty to disclose, because computer hacking is deceptive. Id. at 51. The court remanded to determine whether the hacker actually misrepresented his identity to gain access or simply stole the information. Id. How he gained access would determine whether he actually engaged in a deceptive act. Id.

202. Id. at 49.

203. Id. The SEC argued that the "defendant affirmatively misrepresented himself in order to gain access to material, nonpublic information, which he then used to trade." Id. Thus, the SEC relied not on deception based on nondisclosure but, rather, on deception because of a misrepresentation, because the hacker "'engage[d] in false identification and masquerade[d] as another user."” Id. at 51. 
access or simply stole the information. ${ }^{204}$ Determining precisely how he gained access would establish whether he actually engaged in a deceptive act. $^{205}$

These developments in the evolution of insider trading law are accretional. While none of these developments alone establishes a changed perspective, taken in the aggregate, the picture becomes clear that the fiduciary relationship is no longer the sine qua non of insider trading liability - other kinds of relationships implicate the broader policies of section 10(b) and Rule 10b-5. Thus, it makes less and less sense to base a misappropriation claim on this fiduciary bedrock, when the bedrock itself is being chipped away. If fiduciary duties do not exist between insiders and shareholders, it becomes very difficult to suggest that some relationship evidencing an obligation must exist before an outsider can be held liable.

\section{Unlawful Use of Another's Information as Deception}

As discussed above, to fit within the confines of section 10(b) and Rule 10b-5, courts have characterized insider trading as an omission. The deception necessary to state a claim concerns the trader's failure to disclose in violation of a disclosure obligation. This obligation requires a fiduciary relationship or some other relationship under which this obligation would flow or be created. Characterizing insider trading in this manner, particularly under the misappropriation theory, has led to instances of nonliability where this relationship prerequisite was found not to exist. However, in many, if not all of these cases, the traders in question knowingly and wrongfully took and used another's material, nonpublic information for their own personal gain. ${ }^{206}$ So although they may not have been under any duty to disclose their trading intentions, their use of the information was inherently unlawful. Courts have been forced to ignore these instances of wrongful acquisition and use in the absence of an obligation to disclose trading intentions or keep information confidential. ${ }^{207}$ To recognize this unlawful use of information as deception would take the insider trading claim out of the realm of an omission and attendant duty and place it in the context of an active commission, or misfeasance, where no relationship need exist to

\footnotetext{
204. Id.

205. Id.

206. See supra Part III.

207. See supra Part III.
} 
satisfy a disclosure obligation. My proposal that insider trading be treated as misfeasance should not be misunderstood as suggesting that insider trading submit to a negligence construct. Indeed, the rule requires fraud, and a plaintiff must prove, fraud. ${ }^{208}$ Rather, eliminating the focus of insider trading as a claim of omission and focusing instead on the wrongful use of misappropriated information allows courts to find liability in appropriate situations without having to struggle to find the existence of a special relationship which would give rise to a duty to disclose.

In the wake of the Supreme Court's decision in Stoneridge, courts need not confine insider trading claims to nondisclosure claims. Indeed, courts have recognized this and have attempted to move beyond Chiarella's dictates to find acts of deception independent of a failure to disclose. ${ }^{209}$ In Rocklage, the deceit did not involve failure to disclose in breach of a duty, but rather the wife's act of intentionally eliciting confidential information from her husband while fully intending to share the information with her brother. ${ }^{210}$ It follows from the Rocklage court's attempt to reconcile the illogicality of O'Hagan —allowing a fiduciary to disclose trading intentions to the source and thereby elude liability-that the Rocklage court is disavowing the necessity of the fiduciary relationship in the first place. Rather, the means by which the wife elicited the information furnished the requisite deceit, not any nondisclosure.

Similarly, courts in a variety of computer hacking cases, such as Dorozhko, have concentrated on the manner in which the defendants gained access to information about securities issuers. ${ }^{211}$ These cases focus on the way in which information is obtained, as opposed to the relationship between the parties involved. ${ }^{212}$ One scholar has suggested that this "deceptive acquisition" of confidential information should become the basis for liability under the misappropriation theory. ${ }^{213}$ As Professor Nagy notes, the court in Rocklage started to "embrace a new theory premised on the deceptive acquisition of confidential information, ... but ... failed to make clear that a theory of deceptive

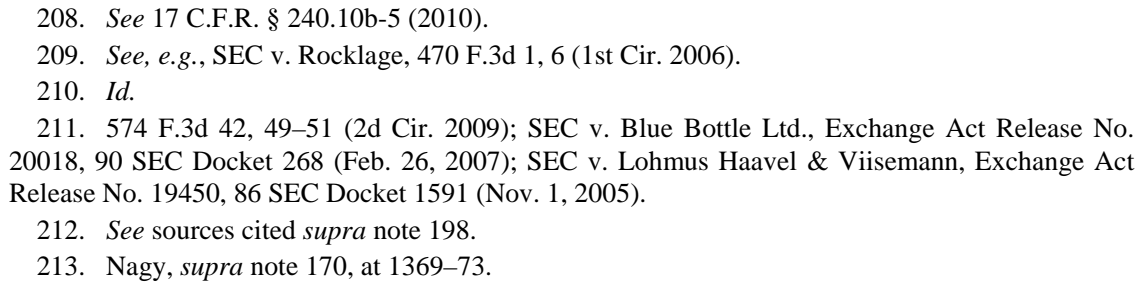


acquisition is analytically distinct from the misappropriation theory endorsed in O'Hagan."214 Even if it had, deceptive acquisition by itself would not catch the next Mark Cuban or J. Thomas Talbot, individuals who legitimately obtained the information in the first place and then traded. Moreover, deceit in the acquisition of information is largely irrelevant unless the information is used for trading. ${ }^{215}$ Thus, the use to which the information is put becomes increasingly more important. Still, the question looms, is the unlawful use of another's confidential information deceptive?

To answer this question, Chiarella is instructive. The starting point for the Supreme Court in Chiarella was the legal effect of Vincent Chiarella's silence. ${ }^{216}$ The Court's adherence to the language in Cady, Roberts \& Co.- that, due to the fiduciary duty insiders owe to shareholders, they are under a duty to either disclose or abstain-created the box within which later insider trading cases must fit. ${ }^{217}$ Characterizing these cases as involving the effect of one's silence necessarily established an insider trading claim as one where silence cannot be fraudulent unless one is under a duty to speak. ${ }^{218}$ And the Court refused to extend this duty to the market generally. ${ }^{219}$ The Court's rejection of a duty to all market participants originated from its concurrent rejection that all market participants are entitled to equal access to market information. ${ }^{220}$ In turn, the Court's rejection of the "parity of information" or "equal access" theory stemmed from its concern that recognition of such a theory would presumably impose on anyone with information a duty to disclose it to the investing public. ${ }^{221}$ But again, this rejection originates from the characterization of insider trading as nondisclosure. ${ }^{222}$ As made clear above, the deception

\footnotetext{
214. Id. at 1369.

215. See, SEC v. Cuban, 620 F.3d 551, 553-55 (5th Cir. 2010) (explaining that use of deceit to obtain information to use in the purchase or sale of securities is illegal).

216. Chiarella v. United States, 445 U.S. 222, 226 (1980).

217. Id. at 226-27.

218. Id. at 230 .

219. Id. at 233.

220. Id. at 233-34.

221. Id. at 234-35.

222. Id. at 236. The Court stated, "We hold that a duty to disclose ... does not arise from the mere possession of nonpublic market information.” Id. at 235.

The Court of Appeals said that its 'regular access to market information' test would create a workable rule embracing 'those who occupy ... strategic places in the market mechanism.' These considerations are insufficient to support a duty to disclose. A duty arises from the relationship between parties ... not merely from one's ability to acquire information because of his position in the market.
} 
necessary to state a claim under section 10(b) has not been so circumscribed. $^{223}$ Thus, using misappropriated information could thereby create liability, not because a duty to disclose has been imposed but because use of the information is deceptive in and of itself.

Even in its Chiarella decision, the Supreme Court recognized ways in which fraud can exist by virtue of other extant duties when outsiders profit on material, nonpublic information. ${ }^{224}$ The Court noted, for example, that tippees have a "duty not to profit from the use of inside information that they know is confidential and know or should know came from a corporate insider." ${ }^{225}$ This example shows precisely how a misfeasance characterization is feasible. Justice Blackmun, in his dissenting opinion in Chiarella, recognized such fraud as a basis for liability. The mere fact that Chiarella stole information that he then used to make money

offers certainly ... the most dramatic evidence that petitioner was guilty of fraud.... even if he had obtained the blessing of his employer's principals before embarking on his profiteering scheme.... [P] etitioner's brand of manipulative trading, with or without such approval, lies close to the heart of what the securities laws are intended to prohibit. ${ }^{226}$

Chief Justice Burger also argued in his dissent that the general rule of nondisclosure in an arm's length transaction should "give way when an informational advantage is obtained, not by superior experience, foresight, or industry, but by some unlawful means.”227 In his concurring opinion, Justice Brennan agreed with Chief Justice Burger, stating that "a person violates [section] 10(b) whenever he improperly obtains or converts to his own benefit nonpublic information which he then uses in connection with the purchase or sale of securities." ${ }^{\text {,28 }}$ These Justices

Id. at 232 n.14 (citation omitted); see also Dirks v. SEC, 463 U.S. 646, 647 (1983) (noting that "[t]he SEC's position that a tippee who knowingly receives nonpublic material information from an insider invariably has a fiduciary duty to disclose before trading rests on the erroneous theory that the antifraud provisions require equal information among all traders. A duty to disclose arises from the relationship between parties and not merely from one's ability to acquire information because of his position in the market”).

223. Stoneridge Inv. Partners v. Scientific-Atlanta, 552 U.S. 148, 158 (2008).

224. Chiarella, 445 U.S. at 230.

225. Id. at 230 n.12. Presumably, a tippee's duty not to profit is derivative of his duty to disclose the insiders or misappropriators who also tip in breach of their duties. The language used by the Court is certainly instructive in framing deception in the absence of fiduciary underpinnings.

226. Id. at 246 (Blackmun, J., dissenting).

227. Id. at 239-40 (Burger, J., dissenting).

228. Id. at 239 (Brennan, J., concurring). 
embraced a "fraud on the investors" misappropriation theory, which suggests that "[i]nsider trading is wrong because it violates a general duty each person owes not to trade on misappropriated material nonpublic information. If a person trades securities on the basis of such information - even with someone to whom he owes no fiduciary dutyhe commits securities fraud.,229

Building on these opinions in Chiarella, leading commentators have argued that a misappropriator of material, nonpublic information has a duty to disclose that information to investors before investing. ${ }^{230}$ Professor Nagy suggests that a duty to disclose exists not merely under a fiduciary construct but also when one party has superior knowledge or special facts that the other party cannot obtain. ${ }^{231}$ This may be particularly true when one with superior knowledge or special facts has obtained them through wrongful or illegal actions. ${ }^{232}$ Professors Strudler and Orts argue in a similar vein and do so from a deontological perspective. ${ }^{233}$ That is, if you use material, nonpublic information that you have no right to use and your doing so will put other investors at an informational disadvantage, from a moral perspective you have wronged that other person. ${ }^{234}$ Based on this reasoning, your failure to disclose is securities fraud. ${ }^{235}$ The suggestion here is similar but different in a critical way-use of misappropriated information does not necessarily give rise to a duty to disclose for which failure to disclose would be fraudulent. Rather, use of misappropriated information is by itself fraudulent.

At its most basic level, wrongful use of material, nonpublic information is simply an extension, or perhaps a simplification, of the continuing evolution of the fiduciary requirement by the courts and the SEC. ${ }^{236}$ In other words, nondisclosure in breach of an obligation to

229. Alan Strudler \& Eric W. Orts, Moral Principle in the Law of Insider Trading, 78 Tex. L. REV. 375, 395 (1999).

230. See Nagy, supra note 29, at 1287-88; Strudler \& Orts, supra note 229, at 399.

231. Nagy, supra note 29, at 1289.

232. Id. at 1289-90.

233. See Strudler \& Orts, supra note 229, at 408-21 (discussing the moral implications of gaining "an informational advantage by luck as compared to effort, skill, or intelligence”).

234. Id. at 419.

235. Id.

236. See Nagy, supra note 170 , at 1319.

Despite the Supreme Court's explicit dictate that fiduciary principles underlie the offense of insider trading, there have been recent repeated instances in which lower federal courts and the [SEC] have disregarded these principles....

... The SEC likewise ignored fiduciary principles in Rule 10b5-2(b)(1). That rule extends liability under the misappropriation theory to securities transactions based on 
disclose is effectively an acknowledgement that the misappropriator has not been as loyal as the source would have expected him to be. The source is led to believe his information is safe and being used appropriately. Yet when someone takes the source's information and uses it for his own personal benefit, has that source not been "duped” just as surely as if the source had a relationship with the person who exploited the information for his own gain?

Consider the ramifications of Rule 10b5-2 on this idea. Has one really been defrauded in the traditional sense when a misappropriator trades in breach of a contractual obligation with him? Has a mother been defrauded when her son fails to keep information she told him in confidence? She might be angry or embarrassed, but has she been defrauded? Did she have an expectation of loyalty such as a traditional fiduciary or similar relationship might create? As the source's expectations of loyalty continue to retreat, the deception necessary for an insider trading claim looks more like wrongful use of information.

Notably, Rule 10b5-2 focuses not on the source's expectations of "loyalty" or confidentiality directly but on the misappropriator's expectations as to the source: Did the person receiving the confidential information know or should he reasonably have known that the source expected that person to keep the information confidential? Although the source may not have any true expectation of confidentiality because of his relationship with the misappropriator, the misappropriator knew or should reasonably have known the source expected him to keep the information confidential, regardless of the kind of relationship they have. This trend in expectations also becomes important in defining the limits of liability for wrongful use as deception. ${ }^{237}$ As the fiduciary requirement gets increasingly watered down, nondisclosure as fraud loses a certain amount of its prior credibility-not because nondisclosure in breach of a duty is no longer deceptive but because the expectation of loyalty created by the relevant relationship has been increasingly diluted. When the expectation of loyalty becomes so diminished such that no "traditional" duty exists, the mere use of confidential information, absent any fiduciary-like relationship between the source and the misappropriator, should suffice as deception, much like Rule 10b5-2

information subject to a confidentiality agreement, regardless of the nature of the relationship between the trader and the information's source. Both SEC rules, however, are consistent with the view that insider trading involves the wrongful use of material nonpublic information regardless of the presence of a fiduciary-like duty. Id. at 1319-20.

237. See infra Part IV.B.5. 
dictates. The trader has perpetuated a false reality that the source's information will be safe and used appropriately. By using the information for personal financial gain, the trader has unlawfully profited at the expense of the source, as well as the shareholders. This weakening fiduciary requirement and expectation of loyalty allows for consideration of the use of misappropriated information as deception because the ideas effectively amount to the same thing: a lack of any true expectation of confidentiality in a traditional fiduciary sense looks a lot like simply taking another's information and using it for one's own personal gain.

This concept of taking and using another's property right to confidential information as satisfying the section 10(b) deception requirement has some teeth in Supreme Court insider trading jurisprudence. Consider the Supreme Court's discussion in Carpenter v. United States of the deception requirement in the mail fraud statute. ${ }^{238}$ The mail fraud statute prohibits using the mail for "any scheme or artifice to defraud, or for obtaining money or property by means of false or fraudulent pretenses, representations or promises." ${ }^{239}$ While the mail fraud statute and section 10(b) apply to different statutory violations, the deceptive conduct underlying both claims is often the same. ${ }^{240}$ Claims for violations of the mail fraud and wire fraud statutes are generally brought alongside securities fraud claims; yet as in section 10(b), Congress provided no precise definition in the mail fraud statute for what constitutes fraud or a deceptive device. Both the district court and court

\footnotetext{
238. 484 U.S. 19, 22 (1987).

239. 18 U.S.C. § 1341 (2006). The mail fraud statute provides:

Whoever, having devised or intending to devise any scheme or artifice to defraud, or for obtaining money or property by means of false or fraudulent pretenses, representations, or promises, or to sell, dispose of, loan, exchange, alter, give away, distribute, supply, or furnish or procure for unlawful use any counterfeit or spurious coin, obligation, security, or other article, or anything represented to be or intimated or held out to be such counterfeit or spurious article, for the purpose of executing such scheme or artifice or attempting so to do, places in any post office or authorized depository for mail matter, any matter or thing whatever to be sent or delivered by the Postal Service, or deposits or causes to be deposited any matter or thing whatever to be sent or delivered by any private or commercial interstate carrier, or takes or receives therefrom, any such matter or thing, or knowingly causes to be delivered by mail or such carrier according to the direction thereon, or at the place at which it is directed to be delivered by the person to whom it is addressed, any such matter or thing, shall be fined under this title or imprisoned not more than 20 years, or both. If the violation occurs in relation to, or involving any benefit authorized, transported, transmitted, transferred, disbursed, or paid in connection with, a presidentially declared major disaster or emergency ... or affects a financial institution, such person shall be fined not more than $\$ 1,000,000$ or imprisoned not more than 30 years, or both.

240. See, e.g., United States v. O’Hagan, 521 U.S. 642, 677-78 (1997) (discussing the interconnectedness of the facts giving rise to a mail fraud claim and a securities fraud claim).
} 
of appeals in Carpenter determined that Winans, a reporter for the Wall Street Journal, "knowingly breached a duty of confidentiality by misappropriating prepublication information regarding the timing and contents of the 'Heard' column, information that had been gained in the course of his employment.... It was this appropriation of confidential information that underlay both the securities laws and mail and wire fraud counts." 241 As a result of this deception, those courts found Winans guilty of violating both section 10(b), as well as the mail and wire fraud statutes. ${ }^{242}$ Since the Supreme Court was evenly divided with regard to the insider trading convictions, it affirmed the Second Circuit's judgment. ${ }^{243}$ With regard to the mail fraud convictions, the Court reasoned that Winans defrauded the Wall Street Journal of its property rights to its confidential business information. ${ }^{244}$

Both courts below expressly referred to the Journal's interest in the confidentiality of the contents and timing of the "Heard" column as a property right, ... and we agree with that conclusion. Confidential business information has long been recognized as property.... We cannot accept petitioners' further argument that Winans' conduct in revealing prepublication information was no more than a violation of workplace rules and did not amount to fraudulent activity that is proscribed by the mail fraud statute. [The mail fraud and wire fraud statutes] reach any scheme to deprive another of money or property by means of false or fraudulent pretenses, representations, or promises. ... [T] he words "to defraud" in the mail fraud statute have the "common understanding" of "wronging one in his property rights by dishonest methods or schemes," and "usually signify the deprivation of something of value by trick, deceit, chicane or overreaching.,"245

Although Winans worked for the Wall Street Journal and as an agent owed it a duty of confidentiality, the Court's language strengthens the argument that deception can occur by depriving another of his property right in his confidential information. ${ }^{246}$ If the deception underlying a

241. Carpenter, 484 U.S. at 23-24.

242. Id. at 24-25.

243. Id. at 24. The Second Circuit reasoned that misappropriation theory liability can arise not only when the misappropriator owes a duty of confidentiality to the corporations whose securities were traded but also when the misappropriator owes this duty to his employer whose securities were not traded. United States v. Carpenter, 791 F.2d 1024, 1028-30 (2d Cir. 1986).

244. Carpenter, 484 U.S. at 25.

245. Id. at 25-27 (quoting McNally v. United States, 483 U.S. 350, 358 (1987)) (internal quotation omitted).

246. Id. at 26-27; see also Randall W. Quinn, The Misappropriation Theory of Insider Trading in the Supreme Court: A (Brief) Response to the (Many) Critics of United States v. O'Hagan, 8 FORDHAM J. CORP. \& FIN. L. 865, 894-95 (2003) (discussing how a computer hacker could be liable 
mail fraud and an insider trading claim is the same conduct, the meaning ascribed to deceptive behavior sufficient to satisfy a claim under each should warrant consistent interpretation. ${ }^{247}$ And the Court's interpretation of deception under the mail fraud statute would encompass using another's misappropriated information.

Yet it has been argued that "stealing"-as misappropriation of confidential information has been called-does not amount to fraud, ${ }^{248}$ and there is little judicial authority to support the idea. ${ }^{249}$ If someone steals your car from a parking lot, you likely have not been defrauded. But if stolen information is used to gain an informational advantage over others who do not possess the same information, the conversion of that information looks less like garden-variety stealing and more like deception. Certainly there is a "deprivation of something of value by trick, deceit, chicane or overreaching." ${ }^{250}$ The source is deceived as to the security of its information, and investors are deceived as to the equal footing upon which they invest. ${ }^{251}$ In fact, this "unfair informational advantage" is what the court in Rocklage identified in eradicating the fiduciary relationship requirement. ${ }^{252}$ Rocklage and the computer hacking cases, such as Dorozhko, illustrate well this concept of stealing as fraud.

Although the courts' rulings in those cases have not necessarily always favored the SEC's position, the SEC appears to be bringing these

for theft of confidential information).

247. See Quinn, supra note 246, at 874-75. Quinn discusses how the deception sufficient in Carpenter to satisfy a mail fraud violation "made clear the validity of a key component of the misappropriation theory-stealing information from one's employer might, under certain circumstances, constitute deception.” Id. Although the mail fraud statute simply requires deception, “not fraud 'in connection with' the purchase or sale of securities” like Rule 10b-5 requires, O'Hagan clarified that a misappropriator's fraud is consummated, not when he gains the confidential information, but when he uses it in a securities transaction. United States v. O'Hagan, 521 U.S. 642, 655-56 (1997). Thus, the deceptive conduct sufficient to give rise to a mail fraud claim gives rise to a securities fraud claim when it is used "in connection with" the purchase or sale of securities.

248. See Bayne, supra note 24, at 144-45; Nagy, supra note 29, at 1255; Saikrishna Prakash, Our Dysfunctional Insider Trading Regime, 99 CoLUM. L. REv. 1491, 1526-27 (1999); Quinn, supra note 246, at 894-95.

249. See infra notes $252-57$ and accompanying text.

250. Carpenter, 484 U.S. at 27.

251. Certainly not every investor has the same information upon which to make securities purchases or sales. The distinction here, however, is driven by the unlawful misappropriation of information, rather than legitimate informational advantages attained by "research or ... derived from publicly available information.” Thomas Lee Hazen, Identifying the Duty Prohibiting Outsider Trading on Material Nonpublic Information, 61 HASTINGS L.J. 881, 883 (2010).

252. SEC v. Rocklage, 470 F.3d 1, 6, 10-11 (1st Cir. 2006). For a discussion on the blurring of fairness and equality and how that blurring plays out in the insider trading context, see Craig W. Davis, Comment, Misappropriators, Tippees and the Intent-to-Benefit Rule: What We Can Still Learn from Cady, Roberts, 35 SETON HALL L. REV. 263, 284-90 (2004). 
kinds of cases with more frequency. One commentator has argued, however, that the rationale-like that in Dorozhko-allowing hacking as deception so long as there has been misrepresentation, leads to uneven results: a thief who misrepresents his identity to obtain the confidential information deceives the source of that information, but the thief who does not use a false identity or some other form of deception to gain access does not. ${ }^{253}$ Yet if both trade, only the imposter-thief is liable, but both trades have equally harmed investors. ${ }^{254}$ Certainly this is true if deception of the source is necessary for liability. ${ }^{255}$ But as discussed above, where one trades on another's information, investors may also be deceived as to the levelness of the playing field upon which they trade. Moreover, this theory suggests that a misrepresentation is necessary for the theft to qualify as deception. Per the Supreme Court's ruling in Stoneridge, if Rule 10b-5 prohibits deceptive conduct, "courts need to look to the functional impact of the conduct. Therefore, if an outsider wrongfully obtains information with the scienter or intent to trade required by section 10 (b), this should be covered by Rule 10b-5."256 This argument should not fall victim to the dictates of Chiarella-that something more than knowing use of nonpublic information is necessary for Rule 10b-5 liability. Instead, this contention focuses on active commission of a wrong - a wrong premised upon the unlawful use of another's information and not on imposing a duty in the context of nonaction. Indeed as one commentator has noted,

given courts' expansion of the misappropriation theory from a narrow version in O'Hagan to the endorsement of the broader liability in Rule 10b5-2, Rocklage's removal of the fiduciary requirement, and the reinvigoration of the version of the misappropriation theory originally outlined in the Chiarella dissent, one is left with the inescapable conclusion that mere thieves are liable for insider trading under Rule $10 \mathrm{~b}-5 .^{257}$

\footnotetext{
253. Hazen, supra note 251, at 902.

254. Id.

255. See infra Part IV.B.4. for a discussion of deception of investors versus deception of the source.

256. Hazen, supra note 251, at 902.

257. Robert Steinbuch, Mere Thieves, 67 MD. L. REv. 570, 608 (2008).
} 


\section{Resolution of O'Hagan's Analytical Inconsistencies Using Misfeasance Deception}

Some of the analytical inconsistencies created by the misappropriation theory may also be resolved if unlawful use could suffice as deception. For example, because nondisclosure serves as the basis for the deception in a misappropriation claim, if the misappropriator discloses his trading intentions to the source, O'Hagan makes clear there has been no deception and thus no securities violation. ${ }^{258}$ However, the animating force behind the securities lawsprotection of investors, promoting investor confidence, and protecting the integrity of the markets-is not furthered when a misappropriator can escape liability by disclosing his trading intentions to the source. ${ }^{259}$ The shareholders have still suffered harm notwithstanding the lack of deceptive conduct. ${ }^{260}$ By connecting the deceptive conduct to the wrongful use of misappropriated information, the deception has been delinked from disclosure. More importantly, the deception has a more appropriate analytical leg to stand on than it does when disclosure permits trading, at least insofar as advancing policy considerations of the securities laws.

Another inconsistency O'Hagan established is the fact that although the source has been defrauded by the misappropriator's nondisclosure, the source will typically have no standing to sue for securities fraud because it is neither a purchaser nor a seller of securities. ${ }^{261}$ The shareholders, however, none of whom have been deceived, do have a right of action. ${ }^{262}$ While asserting use as deception would not necessarily change the standing of the source, the source becomes a lot less relevant in determining the existence of deception because the relationship between the source and the misappropriator may no longer serve as the basis for the deception. Thus, a claim with misappropriation-like facts

\footnotetext{
258. United States v. O’Hagan, 521 U.S. 642, 654-55 (1997).

259. See id.; Nagy, supra note 29, at 1273.

260. O’Hagan, 521 U.S. at 656; Nagy, supra note 29, at 1273, 1276.

261. Nagy, supra note 29, at 1285-87.

262. In Moss v. Morgan Stanley Inc., the court recognized this analytical contradiction and thus held that investors were not defrauded because no duty was owed to them. 719 F.2d 5, 23 (2d Cir. 1983). Congress remedied that result when it adopted section 20A of the Exchange Act, which provides private plaintiffs with express standing to sue any individual who violates any provision of the Exchange Act by trading in securities while in possession of material, nonpublic information. Nagy, supra note 29, at 1283-85. Although section 20A assists private plaintiffs in remedying their claims, it does not assist the government or the SEC when bringing a misappropriation claim. See
} id. 
would have a more plausible underpinning upon which to base liability. ${ }^{263}$

One additional compromise created by O'Hagan is the very concern outlined in the Introduction to this Article: converters of another's information who are not fiduciaries or who do not fall under any of the three scenarios set forth in rule 10b5-2, who then wrongfully use that information for their personal gain, can tip or trade with no repercussions under the securities laws. ${ }^{264}$ As described above, this problem was created by characterizing insider trading as an omission. Thus, the deception is the failure to disclose but only if the trader is under an obligation to disclose. Because there appeared to be no option for insider trading other than to fit within the omission rubric, the misappropriation theory had to do the same. Unfortunately, the absence of any relationship obligating the misappropriator to disclose his trading intentions eliminates liability for stealing another's information and trading on it. Conversely, the misfeasance scenario laid out here would allow for liability.

263. One commentator has made a similar argument, albeit based on a different theoretical underpinning. M. Breen Haire, Note, The Uneasy Doctrinal Compromise of the Misappropriation Theory of Insider Trading Liability, 73 N.Y.U. L. REV. 1251, 1283-84 (1998). For the misappropriation theory to be plausible under section 10(b), the breach of duty to the source of the information, rather than the subsequent improper trading, must be the evil the statute was intended to prevent. Id. at 1283. If this is true, the result should be the "elimination of both private rights of action . . . and secondary liability for employers in misappropriation theory cases." Id. As a result, the Court should "acknowledge that its endorsement of the misappropriation theory was tantamount to an endorsement of the equal access doctrine, and take the dubious step of recognizing a duty among all shareholders to disclose nonpublic information.” Id. at 1284.

264. While Rule 10b5-2 is certainly a helpful tool in successful misappropriation litigation, it probably does not go far enough to solve the problem outlined here. First, Rule 10b5-2's importance derives from its relation to deception as nondisclosure because the Rule identifies scenarios where duties of trust or confidence exist. Second, the SEC has met challenges with regard to how courts interpret the language of Rule 10b5-2. For example, in SEC v. Cuban, the District Court determined that although Mark Cuban agreed to keep the information confidential, the rule did not impose on him an obligation to refrain from trading or otherwise using the information. 634 F. Supp. 2d 713, 730-31 (N.D. Tex. 2009), vacated, remanded, 620 F.3d 551 (5th Cir. 2010). And unfortunately on appeal, the Fifth Circuit declined to rule on Rule 10b5-2's applicability to the case or its validity in general. Cuban, 620 F.3d at 558. Moreover, it is unclear whether Rule 10b5-2 would have permitted liability in cases such as United States v. Kim, 184 F. Supp. 2d 1006 (N.D. Cal. 2002), and SEC v. Kirch, 263 F. Supp. 2d 1144 (N.D. Ill. 2003). In both cases, there is a rather indirect expectation of confidentiality, and no agreement was signed or explicit promise of confidentiality made. Thus, it is not clear Rule 10b5-2(b)(1) would apply. Moreover, although Kim and Kirch were members of groups that may have routinely shared confidences, if the specific parties at issue had never shared confidences at these meetings, would Rule 10b5-2(b)(2) cover that scenario? The court in Kim did not directly rule on the validity of Rule 10b5-2 because it was adopted after the defendant's trading took place, but it did question whether the Rule would apply to the facts. $184 \mathrm{~F}$. Supp. 2d at 1014-15. 
Yet allowing liability for trading on misappropriated information, absent any special relationship, begs the question whether liability should exist anytime one acquires material, nonpublic information and trades on it. This question hearkens back to the earlier days of insider trading jurisprudence when the Court rejected the so-called equal access theory acknowledged earlier by certain courts. ${ }^{265}$ The Court rejected this theory because it was loathe to impose a duty to disclose upon anyone who was in possession of confidential information. ${ }^{266}$ It is not necessary, however, to owe the investor a duty in order to harm him by trading on information to which the investor has no access. Deception as misfeasance would avoid that problem; a court would not have to impose a duty because the wrongdoer has committed an act of active misfeasance-unlawful trading.

Notwithstanding this distinction, however, certain limits on liability should exist. Anyone bringing a misappropriation claim should be able to establish deception by any plausible means. Yet if "deceptive use"meaning the act of trading on another's information-is sufficient to satisfy a claim, does this deceit pick up more potential defendants than is appropriate? Would it catch the person who finds confidential information on a bus that someone has unknowingly dropped? Would it catch the person who overhears a conversation in a restaurant regarding sensitive corporate information? If it does, should it? The next Section attempts to craft limits so as to constrain unrestrained liability.

\section{Crafting the Limits of Liability}

Supreme Court jurisprudence and SEC rulemaking to date advise against allowing liability to exist at these margins identified above. But the state of current law and the judicial machinations courts are forced to devise under the misappropriation theory dictate that SEC or congressional rulemaking is appropriate for clarification of the many constructions of misappropriation liability with an eye toward closing the enforcement gap.

The SEC could create another stand-alone rule, much like it did when it adopted Rule 14e-3, which identifies deceptive conduct in a tender offer context without relying on any fiduciary construct. ${ }^{267}$ Rule

265. Chiarella v. United States, 445 U.S. 222, 232 (1980).

266. See id. at 233.

267. See 17 C.F.R. § 240.14e-3 (2010). Rule 14e-3(a) provides:

(a) If any person has taken a substantial step or steps to commence, or has 
14e-3 effectively creates strict liability for one who trades while in possession of material, nonpublic information regarding a tender offer, regardless of whether any fiduciary duty or similar relationship exists between the source of that information and the trader. ${ }^{268}$ A rule such as this in the Rule 10b-5 context would, however, create liability at the margins which may not be appropriate. Alternatively, the SEC could adopt another subsection within Rule 10b-5 that defines what conduct is deceptive in a misappropriation context to relieve the courts from having to make this determination. ${ }^{269}$ Finally, Congress could amend section 10(b) to provide meaningful guidance. "[G]iven Section 10(b)'s ambiguity and unpredictability_and the resulting circuit splits-as the judiciary traversed the tortuous path of interpreting insider trading regulations, legislative action could set more definite contours of the Rule’s liability."270

Congress had the opportunity to do so during the 1980s but instead enhanced the penalties for insider trading without explicitly defining the requisite conduct sufficient for liability. ${ }^{271}$ A proposed bill during that time, Senate Bill 1380, actually identified the use of wrongfully obtained information as grounds for insider trading liability. ${ }^{272}$ Senate Bill 1380 made it unlawful:

commenced, a tender offer (the "offering person"), it shall constitute a fraudulent, deceptive or manipulative act or practice within the meaning of section 14(e) of the Act for any other person who is in possession of material information relating to such tender offer which information he knows or has reason to know is nonpublic and which he knows or has reason to know has been acquired directly or indirectly from:

(1) The offering person,

(2) The issuer of securities sought or to be sought by such tender offer, or

(3) Any officer, director, partner or employee or any other person acting on behalf of the offering person or such issuer, to purchase or sell or caused to be purchased or sold any of such securities or any securities convertible into or exchangeable for any such securities or any option or right to obtain or to dispose of any of the foregoing securities, unless within a reasonable time prior to any purchase or sale such information and its Id. source are publicly disclosed by press release or otherwise.

268. Id.

269. See Steinbuch, supra note 257, at 609-11 (discussing the options the SEC has for clarifying the insider trading rules).

270. Id. at 611 .

271. Nagy, supra note 170 , at 1366-67.

272. Insider Trading Proscriptions Act of 1987, S. 1380, 100th Cong. § 2(b)(1) (1st Sess. 1987). For the purpose of this section, information shall have been used or obtained wrongfully only if it has been obtained by, or its use would constitute, directly or indirectly, theft, conversion, misappropriation or a breach of any fiduciary, contractual, employment, personal or other relationship of trust and confidence. 
for any person, directly or indirectly, to use material, non public information to purchase or sell any security ... if such person knows or is reckless in not knowing that such information has been obtained wrongfully, or if the purchase or sale of such security would constitute a wrongful use of such information. ${ }^{273}$

This Bill, had it been enacted, would have gone a long way toward closing the enforcement gap that currently exists. It appears to reject liability for those who casually overhear or fortuitously happen upon confidential information. ${ }^{274}$ At the same time, it alleviates the need (in most instances) to determine whether a fiduciary duty or similar relationship of trust and confidence existed before misappropriation liability is appropriate. ${ }^{275}$ Moreover, the Bill does not distinguish between thieves who misrepresent their identity and those who do not. ${ }^{276}$ The rule is premised upon equal access to information not by virtue of a duty imposed on those with the information to disclose it to those who do not but rather inequality as to access as a means of deception. ${ }^{277}$ It trains on active commission of a wrong as deception-trading on another's information. ${ }^{278}$

What this rule may not address is when the trader's acquisition of the information was by purely lawful means, as in such cases as Kim, Talbot, or Cassese, as opposed to unlawful acquisition of information. This question turns on what misappropriation really means. For example, does misappropriation connote unlawfully obtaining another's confidential information, or does it simply mean using another's information, whether lawfully obtained or not? This distinction is critical to balanced closure of the gap currently created by the misappropriation theory. Thus, any rule should clearly define the parameters of what constitutes misappropriated information. It should focus not solely on the use of unlawfully obtained information but also on the use of someone else's information, whether lawfully or unlawfully

273. Id.

274. Id. To more clearly reject liability for such individuals, a rule could focus on the expectations of confidentiality of the source of the information. In other words, if one is discussing confidential information over lunch in a crowded restaurant or leaves confidential papers lying around that others could easily find and use, then the source has little to no expectation of confidentiality. Contrast this with the expectation of confidentiality an employer would have when discussing confidential information in the office with other coworkers. Arguably, the employer should have a greater expectation of confidentiality there than in a public place with outsiders.

275. See id.

276. See id.

277. See id.

278. See id. 
obtained, provided the trader knows or recklessly disregards the fact that the purchase or sale is a wrongful use of the information. Such a rule would closely track the Bill's language. ${ }^{279}$

Assuming liability at the margins is undesirable, a rule would have to address this concern as well. In contrast to the expectations of the trader in Rule 10b5-2, the expectations of the source of the information are important here to avoid such liability. In other words, one should have no expectation of confidentiality when discussing confidential information in a public place. Nor should one have an expectation of confidentiality when one accidentally leaves papers containing confidential information in a public place. Put differently, there should be no deception of the source when the source has no expectation the information will not be used. A more nuanced distinction must be made, however, as to deception of investors in this context. Arguably, the playing field upon which they invest is still not level given another's access to confidential information. Perhaps any fortuitous, accidental acquisition of confidential information might be deemed a legitimate informational advantage, particularly because there is no " deprivation of something of value by trick, deceit, chicane, or overreaching."”280 Any meaningful clarity Congress or the SEC could bring to the insider trading laws would increase consistency of judicial decision-making, would enhance investor protection and integrity of the markets, and would create a coherent approach to insider trading liability.

\section{Does Scienter Exist in the Misfeasance Context?}

Scienter has long been an element of an insider trading claim. ${ }^{281}$ Scienter is "a mental state embracing intent to deceive, manipulate, or defraud."282 Although the pleading requirement for scienter has undergone considerable debate, ${ }^{283}$ the substantive standard for scienter

279. See id.

280. Carpenter v. United States, 484 U.S. 19, 27 (1987) (quoting McNally v. United States, 483 U.S. 350, 358 (1987)).

281. See Ernst \& Ernst v. Hochfelder, 425 U.S. 185 (1976).

282. Id. at 193 n.12.

283. The Private Securities Litigation Reform Act (PSLRA) was enacted by Congress to provide a check against abusive securities fraud litigation by private parties. Tellabs, Inc. v. Makor Issues \& Rights, Ltd., 551 U.S. 308, 313-14 (2007) (discussing 15 U.S.C. § 78u-4 (2006)). Section 21D(b)(2) of the PSLRA requires plaintiffs to "state with particularity facts giving rise to a strong inference that the defendant acted with the required state of mind." 15 U.S.C. § 78u-4(b)(2). Congress, however, left the term strong inference undefined, and courts of appeals were divided as to its meaning until the Supreme Court's decision in Tellabs, 551 U.S. at 314. In Tellabs, the 
itself has remained unchanged. Every circuit court that has considered the issue has determined that scienter may be established by a showing of intent to deceive or recklessness, and the Supreme Court has not yet ruled on that issue. ${ }^{284}$ If the requirement for deception is met by the use of another's information so long as "such person knows (or recklessly disregards) that such information has been obtained wrongfully, or that such purchase or sale would constitute a wrongful use of such information," 285 it necessarily follows that scienter exists as well. Courts have looked to opportunistic timing of trades once the trader becomes aware of the confidential information to satisfy an allegation of scienter, ${ }^{286}$ as well as whether the defendant knew the information was unlawfully obtained. ${ }^{287}$ Thus, it appears that under a misfeasance construct, both the deception and scienter requirements necessary to state a claim would exist.

\section{CONCLUSION}

Mark Cuban escaped liability in the district court because his relationship with Mamma.com was insufficient to establish a duty to disclose. Moreover, the agreement he made with Mamma.com's CEO to keep the information regarding the proposed PIPE offering confidential was insufficient to impose any duty on him not to trade on the information he learned. Even though Cuban stated he could not sell given his knowledge of material, nonpublic information, he sold anyway. Yet under current misappropriation theory, the district court held him not liable for insider trading. Moreover, notwithstanding its reversal of the district court, the Fifth Circuit did little to ensure a clear understanding of whether Cuban owed Mamma.com a duty not to trade on the information.

The characterization of insider trading as fraud by omission has created problems for enforcement efforts in the misappropriation context. Individuals who have no fiduciary duty or similar relationship with the source of the misappropriated information can escape liability,

Supreme Court held that to determine whether a complaint's scienter allegations are sufficient, a court must consider inferences urged by the plaintiff and also competing inferences rationally drawn from the facts alleged. Id. "To qualify as 'strong' within the intendment of §21D(b)(2), we hold, an inference of scienter must be more than merely plausible or reasonable-it must be cogent and at least as compelling as any opposing inference of nonfraudulent intent.” Id.

284. Tellabs, 551 U.S. at 319 n.3.

285. Insider Trading Proscriptions Act of 1987, S. 1380, 100th Cong. § 2(b) (1st Sess. 1987).

286. SEC v. Kornman, 391 F. Supp. 2d 477, 493 (N.D. Tex. 2005).

287. Id.; see also United States v. Mylett, 97 F.3d 663, 668 (2d Cir. 1996). 
notwithstanding the fact they took another's material, nonpublic information and used it for trading purposes, resulting in significant personal profits or avoidance of financial losses. The mere fact that no relationship exists requiring these traders to disclose their trading intentions in no way diminishes the wrongfulness of their actions. Thus, to find insider trading liability by virtue of a commission of a wrong (misfeasance), as opposed to a failure to disclose (nonfeasance), would allow appropriate liability without necessitating obstructive line-drawing.

Allowing insider trading liability due to use of another's information still comports with Rule 10b-5 requirements for liability. The necessary deception exists in the commission of the wrong itself. For example, Mark Cuban arguably deceived Mamma.com by promising to keep the information confidential, yet trading on it anyway. Because he used another's information for commission of a knowingly wrongful trade, the requisite deception exists. Moreover, he arguably deceived Mamma.com's shareholders. Cuban avoided significant losses when he sold using information other shareholders were not privy to. The deception lies in the irregularity of the playing field upon which they all traded. And as Cuban's trades were knowingly wrong-by his own admission-he satisfies the scienter requirement for liability.

While many may find this proposed change, and resultant expansion of liability, an anathema, the fact is that section 10(b) and Rule 10b-5 do not require a fiduciary duty or similar relationship of trust and confidence to satisfy the necessary deception. Deception may exist by any appropriate means. To require such a relationship creates an inevitable enforcement gap, as well as judicial inconsistencies. Allowing the use of the information itself to serve as the basis for liability will close this gap and provide greater consistency, congruency, and stability. One who trades improperly on another's information is at least as culpable as the inside corporate executive, and the laws should reflect this culpability. 